\title{
Characteristics of Intense Convection in Subtropical South America as Influenced by El Niño-Southern Oscillation
}

\author{
ZACHARY S. BRUICK AND KRISTEN L. RASMUSSEN \\ Department of Atmospheric Science, Colorado State University, Fort Collins, Colorado \\ Angela K. Rowe ANd Lynn A. MCMurdie \\ Department of Atmospheric Sciences, University of Washington, Seattle, Washington
}

(Manuscript received 20 September 2018, in final form 26 February 2019)

\begin{abstract}
El Niño-Southern Oscillation (ENSO) is known to have teleconnections to atmospheric circulations and weather patterns around the world. Previous studies have examined connections between ENSO and rainfall in tropical South America, but little work has been done connecting ENSO phases with convection in subtropical South America. The Tropical Rainfall Measuring Mission (TRMM) Precipitation Radar (PR) has provided novel observations of convection in this region, including that convection in the lee of the Andes Mountains is among the deepest and most intense in the world with frequent upscale growth into mesoscale convective systems. A 16-yr dataset from the TRMM PR is used to analyze deep and wide convection in combination with ERA-Interim reanalysis storm composites. Results from the study show that deep and wide convection occurs in all phases of ENSO, with only some modest variations in frequency between ENSO phases. However, the most statistically significant differences between ENSO phases occur in the threedimensional storm structure. Deep and wide convection during El Niño tends to be taller and contain stronger convection, while La Niña storms contain stronger stratiform echoes. The synoptic and thermodynamic conditions supporting the deeper storms during El Niño is related to increased convective available potential energy, a strengthening of the South American low-level jet (SALLJ), and a stronger upper-level jet stream, often with the equatorward-entrance region of the jet stream directly over the convective storm locations. These enhanced synoptic and thermodynamic conditions provide insight into how the structure of some of the most intense convection on Earth varies with phases of ENSO.
\end{abstract}

\section{Introduction}

Precipitating systems are a critical component of Earth's hydrologic and energy budgets by redistributing moisture and energy. Extreme precipitation events usually take the form of convective storms, which have a large socioeconomic impact through flooding, large hail, and extreme winds. Around the world, the variability of convection causes hydrological extremes such as droughts and floods that significantly affect large regions for an extended amount of time. Additionally, the occurrence of extreme events and associated severe weather impacts have been related to large-scale climate variability (Cook and Schaefer 2008; Tippett et al. 2015; Rasmussen et al. 2014; Cook et al. 2017) with one

\footnotetext{
Corresponding author: Zachary S. Bruick, zbruick@ rams.colostate.edu
}

notable example of large-scale variability being El NiñoSouthern Oscillation (ENSO). ENSO is an interannual fluctuation of tropical Pacific Ocean sea surface temperatures and the surface pressure difference between Darwin and Tahiti (Trenberth 1997) that is known to affect the variability of temperature and precipitation globally on an interannual cycle through teleconnections (Wallace and Gutzler 1981; Horel and Wallace 1981; Rasmusson and Carpenter 1983; Ropelewski and Halpert 1987; Halpert and Ropelewski 1992; Dai 2001). Thus, a greater understanding of the role of ENSO on the global variability of convection and associated severe weather and flooding will help improve high-impact weather predictability.

Under neutral ENSO conditions, the Walker circulation transports warm, moist air to the western Pacific Ocean where it rises and returns aloft to the eastern Pacific where it descends and flows west once more 
(Bjerknes 1969). During the warm phase of ENSO, commonly referred to as El Niño, the Walker circulation weakens or breaks down, leading to the anomalous convergence of air in the central Pacific Ocean and an increase in the frequency of convection and lightning there (Chronis et al. 2008), and anomalous subsidence over tropical South America (Shimizu et al. 2017). During the cold phase of ENSO, known as La Niña, the Walker circulation strengthens, but remains in the same place as in neutral conditions, with a rising branch of the circulation over tropical South America. Additionally, the Hadley circulation, which has its rising branch near the equator and sinking branch at $30^{\circ} \mathrm{S}$, is weakened during El Niño by the reduced convective activity in northern South America (Grimm and Ambrizzi 2009).

These changes in the Walker and Hadley circulations modulate global circulations by disrupting the propagation of Rossby waves generated by tropical convection (Grimm and Ambrizzi 2009). Therefore, ENSO impacts convection globally. In the United States, increased rainfall from mesoscale convective systems (MCSs) (Anderson and Arritt 2001) and increased precipitation over the southern states and Gulf of Mexico (Dai 2001; Lee et al. 2014) are correlated with El Niño, while more severe weather events in the southeast United States occur during La Niña (Allen et al. 2015). In Southeast Asia, El Niño causes higher surface pressure over the ocean, leading to onshore flow and increased precipitation over land (Yoshida et al. 2007). During El Niño farther south, colder ocean waters surrounding Indonesia suppress convection, which leads to enhanced drought conditions during summer (Hendon 2003).

Recent research has examined how ENSO affects rainfall in tropical regions of South America, such as the Amazon rain forest in northern South America. Shimizu et al. (2017) showed that the Amazon and northeastern Brazil are drier during El Niño due to anomalous subsidence from disrupted Walker and Hadley circulations. This result corroborated previous studies that found that warmer tropical central Pacific Ocean temperatures during El Niño shortened the convective season in the Amazon (Liebmann and Marengo 2001) and decreased rainfall over the northeastern Amazon and southern tropical Andes mountains (Espinoza Villar et al. 2009). In subtropical South America, correlations between rainfall and ENSO have been demonstrated, especially for the La Plata basin encompassing northeast Argentina, Paraguay, and southeastern Brazil. Rainfall tends to be maximized in this area during El Niño, leading to flooding within the basin (Camilloni and Barros 2003; Cavalcanti et al. 2015). Synoptic forcing for enhanced rainfall in the La Plata basin may be provided by a stronger subtropical jet with increased cyclonic vorticity advection, as well as enhanced moisture advection from the Amazon and tropical Atlantic Ocean into the basin (Karoly 1989; Grimm et al. 2000; Grimm and Tedeschi 2009). However, an understanding of how specific characteristics of precipitation systems and convective storms in subtropical South America are influenced by ENSO is lacking given the remote location and general scarcity of ground-based observations in the region.

The Tropical Rainfall Measuring Mission (TRMM) Precipitation Radar (PR) is the only long-term observational dataset available to examine convection in subtropical South America. Using the TRMM PR, convection in this region has been found to be some of the most intense anywhere on Earth (Zipser et al. 2006; Romatschke and Houze 2010; Houze et al. 2015). Storms frequently initiate near the elevated terrain of the Andean foothills and the Sierras de Córdoba (SDC) in western and central Argentina (Fig. 1). Rasmussen and Houze (2016) developed a conceptual model to show why this region is highly favored for convective initiation and subsequent upscale growth. Convergence is maximized near the SDC due to the impingement of the South American low-level jet (SALLJ) from the north and ageostrophic midlevel flow from the south on the elevated terrain. Because of the descent of upperlevel air in the lee of the Andes, a mechanical capping inversion exists over the region that inhibits convective initiation. Moisture is advected into subtropical South America from the Amazon rain forest to the north via the SALLJ and from the subtropical Atlantic Ocean to the northeast, which destabilizes the near-surface atmosphere. With sufficient topographic forcing provided by the SDC and the Andean foothills, the capping inversion is broken and convective initiation occurs (Rasmussen and Houze 2016). Storms initially grow very deep and are capable of producing large hail, strong winds, and flooding rains (Rasmussen et al. 2014). As storms move east off the terrain, they tend to grow upscale into MCSs, occasionally featuring repeated development of intense convective elements along the terrain referred to as back-building due to continued moisture advection and uplift by the SALLJ (Velasco and Fritsch 1987; Rasmussen et al. 2014; Rasmussen and Houze 2011, 2016). MCSs provide approximately $15 \%-$ $21 \%$ of annual rainfall (Durkee et al. 2009) and $44 \%$ of the warm-season rainfall (Rasmussen et al. 2016) in the La Plata basin, making them important rainfall producers during the growing season.

Because of the extreme nature of convection in subtropical South America, with regards to intensity and frequency, improved understanding of how different 


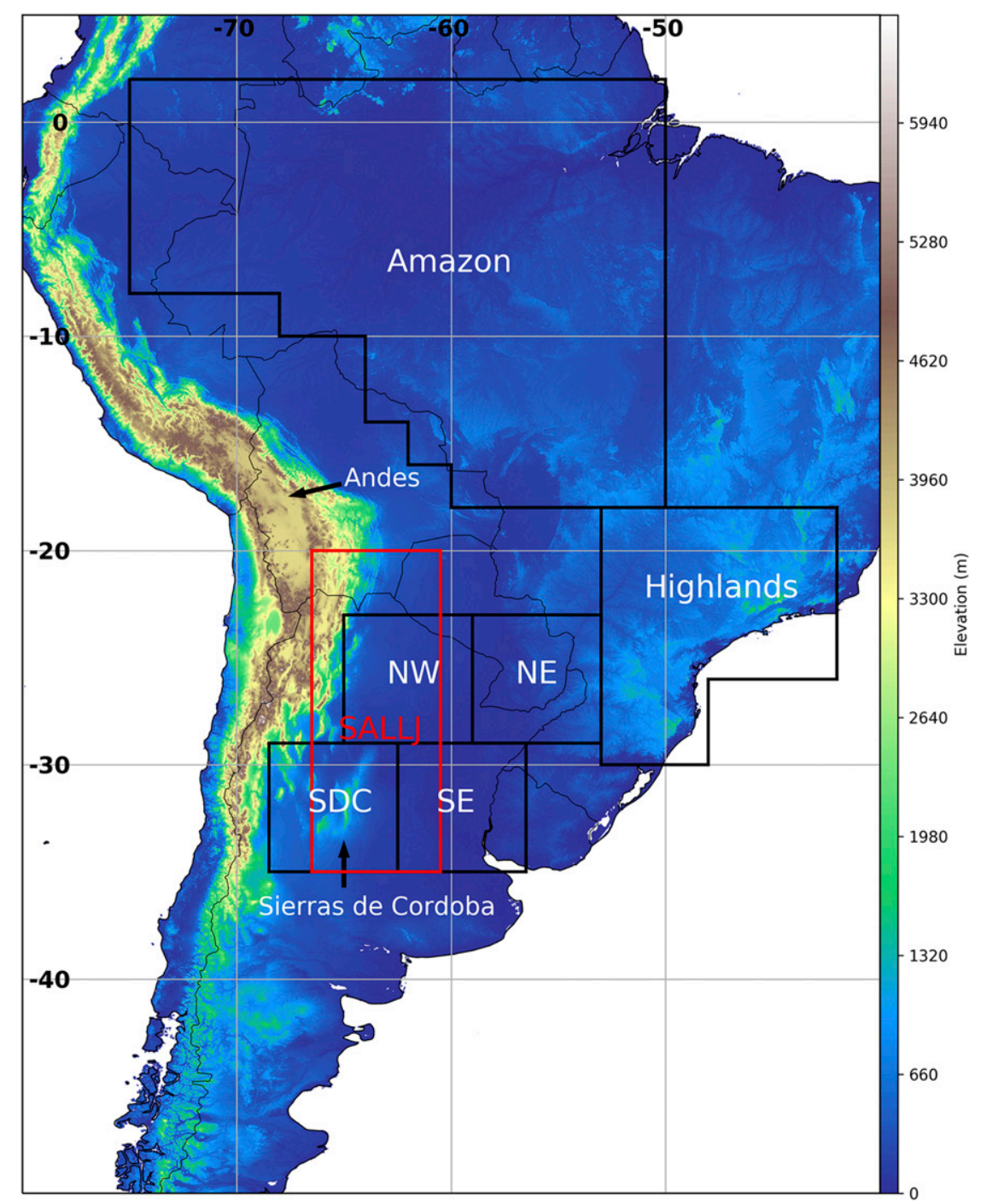

FIG. 1. South America with topography and study sectors overlaid. The four $6^{\circ}$ by $6^{\circ}$ primary sectors are located in northern Argentina and Paraguay and the Amazon and Highland comparison sectors are based on the climatology of Rasmussen et al. (2016). The South American low-level jet (SALLJ) region is based on Rasmussen and Houze (2016).

phases of ENSO may affect the frequency, intensity, and storm characteristics of high-impact storms in this region will broadly enhance knowledge on the interactions of deep convection and complex topography in varying environments. This study examines how the frequency and characteristics of convection change with respect to El Niño and La Niña in subtropical South America. Variations in synoptic conditions between El Niño and La Niña, derived from reanalysis data, help to explain the differences in convective characteristics found in the satellite observations. Additionally, these results provide insight on important synoptic conditions leading to some of the most intense convection in the world. Storms in subtropical
South America occur over important agricultural areas that support a large portion of the region's economy, thus a greater understanding of the variability of highimpact storms in the region have large socioeconomic benefits. Finally, this study will provide context as to how ENSO may impact the Remote sensing of Electrification, Lightning, and Mesoscale/microscale Processes with Adaptive Ground Observations (RELAMPAGO) field campaign, ${ }^{1}$ which seeks to further the understanding of convective storms in Argentina through extensive field observations.

\footnotetext{
${ }^{1}$ https://www.eol.ucar.edu/field_projects/relampago
} 


\section{Methodology}

To study the intense convection in subtropical South America concentrated near the Andes and SDC (Romatschke et al. 2010; Rasmussen and Houze 2011; Rasmussen et al. 2016), four primary sectors, each $6^{\circ}$ by $6^{\circ}$, are defined over this area (Fig. 1). These regions contain much of subtropical South America and will be referred to as such throughout the study. The southwestern sector (SDC) is located over the SDC range. The northwest (NW) sector is located north of the SDC sector with its western edge along the lee slope of the Andes, as convection is known to initiate along the terrain in this region. The northeast (NE) and southeast (SE) sectors are located immediately to the east of the NW and SDC sectors, respectively, to capture the upscale growth of MCSs as they move east off the high terrain (Rasmussen and Houze 2011, 2016; Rasmussen et al. 2014). The Amazon and Highlands regions are included as reference areas (Rasmussen et al. 2016) to compare to previous ENSO studies in tropical South America (e.g., Grimm et al. 2000; Liebmann and Marengo 2001; Espinoza Villar et al. 2009).

To assess the phase of ENSO in any given month, the Niño-3.4 standardized temperature anomalies are used. The Niño-3.4 region extends from $5^{\circ} \mathrm{N}-5^{\circ} \mathrm{S}$ and $120^{\circ}-$ $170^{\circ} \mathrm{W}$ in the central tropical Pacific Ocean. This region has been used by the National Centers for Environmental Prediction's Climate Prediction Center since 1996 to analyze the phase and magnitude of ENSO (Trenberth 1997). The standardized anomalies are calculated using the Hadley Centre Sea Ice and Sea Surface Temperature dataset, version 1 (HadISST1; Rayner et al. 2003). An El Niño or La Niña event is determined to have occurred if the standardized temperature anomaly is above or equal to $0.5 \mathrm{~K}$, or below or equal to $-0.5 \mathrm{~K}$, respectively, for six months or longer (Trenberth 1997). This index has been used in many studies, including the recent studies of Blamey et al. (2017), Sulca et al. (2017), and Parhi et al. (2016), although they make use of other, but similar, oceanic temperature reanalysis datasets.

To analyze the characteristics of convection, a 16-yr dataset (1998-2013) from TRMM is utilized. The TRMM PR had a high spatial resolution $(4-5 \mathrm{~km}$ horizontal, $250 \mathrm{~m}$ vertical), with coverage between $36^{\circ} \mathrm{N}$ and $36^{\circ} \mathrm{S}$ (Kummerow et al. 1998, 2000). Three TRMM data products are used in this study:

- 2A23 (rain characteristics; Awaka et al. 1997), where TRMM orbital precipitation data are separated into the three categories of convective, stratiform, and other.

- 2A25 (rainfall rate and profile; Iguchi et al. 2000), which contains the TRMM orbital three-dimensional attenuation-corrected reflectivity data.
- 3B43 (rainfall climatology; Huffman et al. 2007), which provides gridded monthly multisatellite calibrated precipitation, output on a monthly basis.

Following the methodology of Houze et al. (2007), the TRMM PR data are processed from the original orbital data from the conical-scanning radar and is remapped by implementing a geolocation algorithm and interpolated into Cartesian coordinates. Using this data, storms containing deep and wide convective echoes are identified using a methodology established by Houze et al. (2007). Deep convective cores (DCCs) are threedimensional contiguous cores with $40-\mathrm{dB} Z$ echoes $\geq 10-\mathrm{km}$ altitude and represent vigorous convection that contains strong and tall updrafts early in the convective life cycle. Wide convective cores (WCCs) are three-dimensional contiguous $40-\mathrm{dB} Z$ echoes with maximum horizontal area coverage of $\geq 1000 \mathrm{~km}^{2}$ and are representative of MCSs that have become very large horizontally yet remain extremely intense, which allows them to be capable of producing substantial rainfall and occasional severe weather (Houze 2004). Deep and wide convective cores (DWCCs) must meet the criteria of both DCCs and WCCs and are an exclusive category so that no storms exist in more than one category. DWCCs represent vigorous convection that has begun to grow upscale with intense horizontal and vertical components. These methods have been utilized by numerous studies including Romatschke et al. (2010), Rasmussen et al. (2014, 2016), Rasmussen and Houze (2011, 2016), Qie et al. (2014), Sen Roy et al. (2014), Zuluaga and Houze (2015), and many others. While the method described above identifies convective cores using TRMM PR data, the full storm that each convective core is embedded within is analyzed in the current study to present a holistic picture of how convective systems may vary due to ENSO. Twosided $t$ tests were conducted on the TRMM-derived storm characteristics to identify statistically significant differences between ENSO phases.

The TRMM PR rainfall algorithm is known to underestimate precipitation produced by deep convection over land (Iguchi et al. 2009; Rasmussen et al. 2013). Therefore, rainfall was instead estimated with the $Z-R$ relationship used by Rasmussen et al. (2013), $Z=a R^{b}$, where $Z$ is the radar reflectivity factor $\left(\mathrm{mm}^{6} \mathrm{~m}^{-3}\right)$ and $R$ is the corrected rain rate $\left(\mathrm{mm} \mathrm{h}^{-1}\right)$. The parameters $a$ and $b$ are constants based on rain type. The values used to calculate rainfall in this study were previously implemented by Romatschke and Houze (2011) and Rasmussen et al. $(2013,2016)$ for typical subtropical land-based rainfall, where $a=100$ and $b=1.7$ for convective rain, and $a=200$ and $b=1.49$ for stratiform rain. 
To analyze the vertical structure of storms containing DCCs, DWCCs, and WCCs, contoured frequency by altitude diagrams (CFADs) are used (Yuter and Houze 1995). These plots compress three-dimensional data into a two-dimensional histogram in order to show the frequency of a specific reflectivity echo at a particular altitude. The frequency is normalized at each level by the most frequent reflectivity bin found within that level. Precipitation-type CFADs are created using the 2A23 TRMM product to distinguish between stratiform and convective rain.

Synoptic and environmental conditions are derived from ERA-Interim (Dee et al. 2011) with all variables computed at 1800 UTC on the day of storm occurrence. El Niño and La Niña climatological conditions are composited from 1980-2009 using the ERA-Interim Synoptic Monthly Means product, with months selected for each ENSO phase based on the Niño-3.4 temperature anomalies discussed above.

\section{ENSO climatological rainfall and synoptic conditions}

During El Niño, much of subtropical South America, including the four primary sectors, experiences increased rainfall on the order of $20-60 \mathrm{~mm}$ more per month than climatology (Fig. 2a). Enhanced rainfall is maximized across northeastern Argentina and southeastern Brazil, with almost no difference between El Niño months and climatology across the Andean foothills in western Argentina. During La Niña, the pattern reverses, with diminished rainfall compared to climatology across northeastern Argentina and southeastern Brazil, including the NE and SE study regions and enhanced rainfall over the SDC and NW regions (Fig. 2b). Rainfall also increases during La Niña in Bolivia and western Brazil. It is important to note that rainfall correlates with ENSO seasonally in this region, as previous research has shown that the strongest correlations between El Niño and rainfall occur in the spring across northern Argentina (Gonzalez et al. 2017).

The precipitation anomaly results during El Niño are similar to findings from Ropelewski and Halpert (1987) and Souza and Ambrizzi (2002). Both studies found precipitation maxima in the La Plata basin during El Niño periods using surface and satellite measurements, respectively. Ropelewski and Halpert (1987) hypothesize that this precipitation anomaly is due to stronger upper-level westerly flow and increased low-level convergence. Grimm and Tedeschi (2009) found that the regional circulation over eastern Brazil tends to be cyclonic during El Niño. This circulation brings more moisture to subtropical South America, which helps to increase precipitation. The increased La Niña rainfall in Bolivia and western Brazil found in this study concurs with previous surface station results from Espinoza Villar et al. (2009) and Shimizu et al. (2017). Increased rainfall over the Amazon during La Niña is a result of increased moisture convergence due to a regional anticyclonic circulation (Grimm and Tedeschi 2009) and a strengthened Walker circulation (Shimizu et al. 2017).

Enhanced low- and upper-level jet streams and a broader lee trough during El Niño are highlights of the climatological synoptic conditions for El Niño and La Niña, using 1980-2009 ERA-Interim composites (Fig. 2). The 850-hPa winds are stronger near the elbow of the Andes and into Paraguay during El Niño, indicating an enhancement of the SALLJ (Fig. 2c). The upper-level jet is stronger during El Niño, with maximum climatological wind speeds exceeding $30 \mathrm{~m} \mathrm{~s}^{-1}$ over the central Andes and from east-central Argentina into the southern Atlantic Ocean (Fig. 2e), with the maximum difference occurring during spring (not shown). This increased upper-level jet strength over subtropical South America during El Niño was originally noted by Arkin (1982) and hypothesized to be a result of a strengthened Hadley circulation during El Niño (Kousky et al. 1984). Additionally, a broader lee trough exists at $850 \mathrm{hPa}$ during El Niño, where the 1500-m geopotential height contour extends farther east into central Argentina (Figs. 2c,d). This feature is also evident in the surface mean sea level pressure field (not shown). Lee cyclogenesis has been identified as a key feature associated with convection in subtropical South America (Rasmussen and Houze 2016) and has been identified in the United States as being present before severe convection initiates in some cases (e.g., Karyampudi et al. 1995). Moisture within the SALLJ box outlined in Fig. 1 is comparable between El Niño and La Niña (Table 1). However, moisture advection into the study regions is slightly enhanced during $\mathrm{El}$ Niño (Table 1) due to the stronger and broader low-level jet (Fig. 2c). With increased moisture advection, and stronger lower- (Table 1) and upper-level jets, storm environments in subtropical South America are enhanced on average during El Niño conditions relative to La Niña.

\section{Variability of convective storms and their environments during ENSO}

\section{a. Synoptic environment differences}

Although the study period is limited to the lifetime of the TRMM satellite, a large number of convective storms were captured by the TRMM PR across four El Niños and four La Niñas (Fig. 3) during austral spring and summer, enabling further analysis into differences 

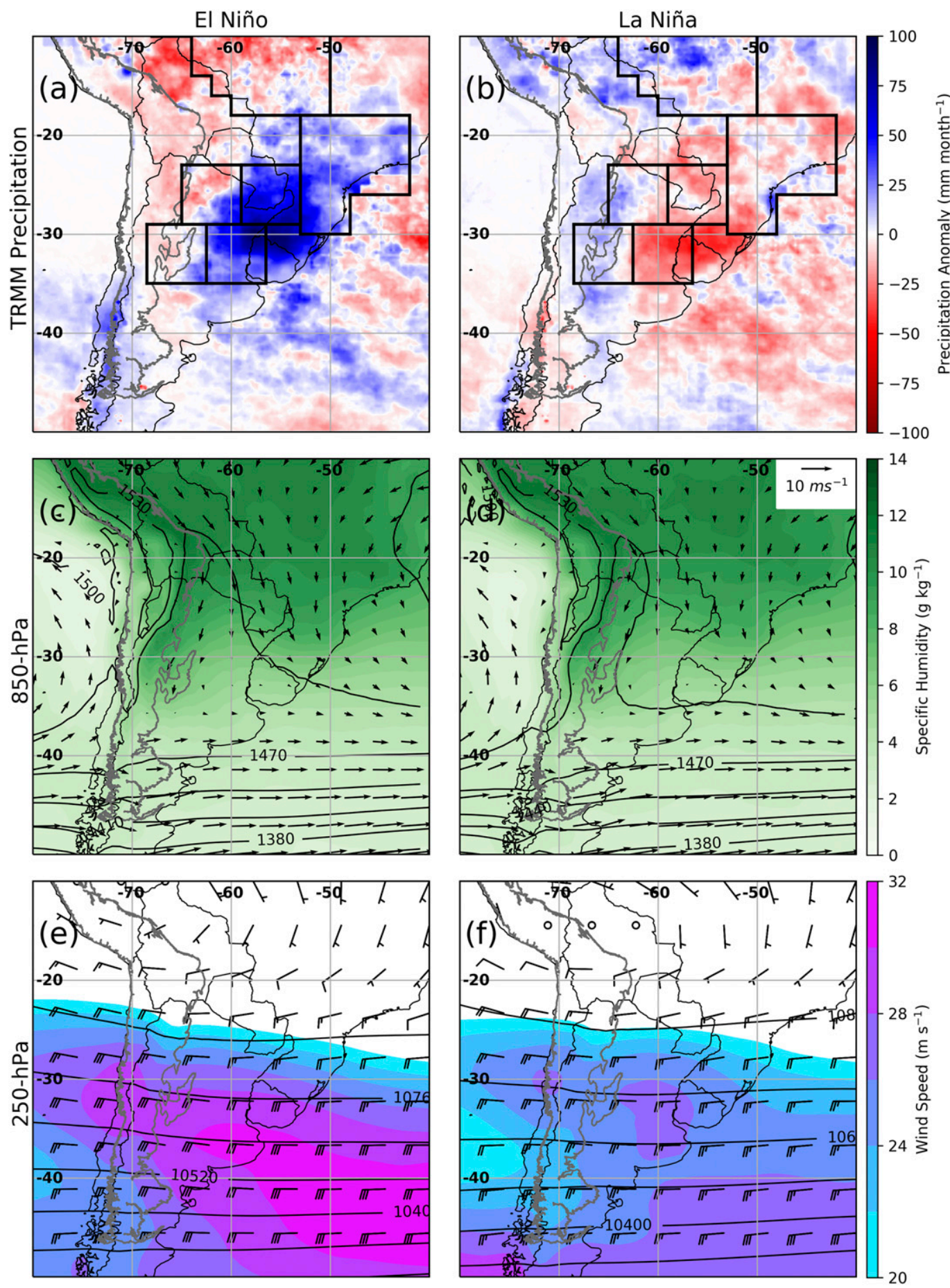

FIG. 2. (a),(b) Differences between El Niño and La Niña rainfall from TRMM climatology (mm month ${ }^{-1}$ ), respectively, for September through May. (c),(d) The ERA-Interim 1980-2009 composite climatology is shown for El Niño and La Niña 850-hPa geopotential height (m), wind speed $\left(\mathrm{m} \mathrm{s}^{-1}\right)$, and specific humidity $\left(\mathrm{g} \mathrm{kg}^{-1}\right)$, and (e),(f) 250-hPa geopotential height and wind speed. The 500-m topographic isopleth is contoured in gray and the sectors outlined in Fig. 1 are included in (a) and (b) for reference. 
TABLE 1. 850-hPa climatological conditions within the SALLJ box outlined in Fig. 1.

\begin{tabular}{lccc}
\hline & 850-hPa specific humidity $\left(\mathrm{g} \mathrm{kg}^{-1}\right)$ & $850-\mathrm{hPa}$ winds $\left(\mathrm{m} \mathrm{s}^{-1}\right)$ & 850-hPa moisture advection $\left(\mathrm{g} \mathrm{kg}^{-1} \mathrm{~s}^{-1}\right)$ \\
\hline El Niño & 7.50 & 2.89 & 27.18 \\
La Niña & 7.48 & 2.64 & 15.75 \\
\hline
\end{tabular}

in storm characteristics and their supporting synoptic environments between ENSO phases. To assess the differences between the climatological El Niño and La Niña environments with convective environments that occurred during these ENSO phases, synoptic composite differences are analyzed. Convective days are identified as days that contained any number of DCCs, DWCCs, and WCCs within the four primary study regions. It is important to note that high terrain may present challenges to reanalysis models in the lower levels of the atmosphere, specifically near the steep slopes of the Andes Mountains, where the terrain gradient is not easily resolved.

For convective days during El Niño in austral spring, a stronger surface lee cyclone is present compared to the El Niño climatology over the border of Bolivia, Paraguay, and Argentina (Fig. 4a). This anomalous low pressure system may be an enhancement and displacement of the northwestern Argentina low (NAL), a climatological feature of this area (Lichtenstein 1980; Seluchi et al. 2003). The enhancement and displacement of the NAL may promote stronger warm air and moisture advection, as well as improved orographic lift, through enhanced synoptic flow near the surface. At $850 \mathrm{hPa}$, increased moisture exists throughout the plains of subtropical South America, with a maximum increase in northeastern Argentina, for El Niño convective days compared to climatology (Fig. 4c). Northerly winds are reduced in magnitude during convective days, indicating a weaker low-level jet is present during these days as compared to climatology. However, at $250 \mathrm{hPa}$, the upper-level jet stream increases in strength during convective days from climatology by $6-9 \mathrm{~m} \mathrm{~s}^{-1}$ (Fig. 4e). This anomaly is located in the same place as the climatological jet stream during El Niño (Fig. 2e), so this increase in wind speed during austral spring El Niño convective days represents an increase in the overall speed of the jet stream and not a latitudinal displacement of the jet stream. Increased jet strength would enable stronger secondary circulations, which would cause stronger rising motion over the primary study regions.

Similarly for La Niña, a stronger lee cyclone is present at the surface during austral spring convective days compared to climatology (Fig. 4b). Furthermore, moisture increases and meridional winds decrease at $850 \mathrm{hPa}$ along the plains immediately east of the Andean foothills
(Fig. 4d). However, at $250 \mathrm{hPa}$, the wind speed anomalies are not nearly as strong with increases of only $1-3 \mathrm{~m} \mathrm{~s}^{-1}$ across subtropical South America (Fig. 4f). This difference would not substantially change the strength of the secondary circulations within the jet stream. The differences between convective days and climatology during austral summer are similar to the austral spring La Niña differences for both El Niño and La Niña (not shown).

Comparing convective days during El Niño and La Niña allows their influences on the synoptic environment in South America to be examined. Because composites were similar between storm types (not shown), all three categories of extreme convection were combined by ENSO phase to produce a single synoptic composite difference. At the surface, El Niño convective days are warmer than La Niña convective days in tropical South America and along the Andean foothills south to the SDC during austral spring but not summer (Figs. 5a,d). Rather, during summer, the 2-m temperature is cooler by about $1^{\circ} \mathrm{C}$ in the central plains of Argentina. Farther south and east, El Niño convective days are cooler than La Niña convective days during both seasons. The dewpoint temperatures slightly increase during El Niño convective days compared to La Niña by $1^{\circ} \mathrm{C}$ over the La Plata basin (not shown).
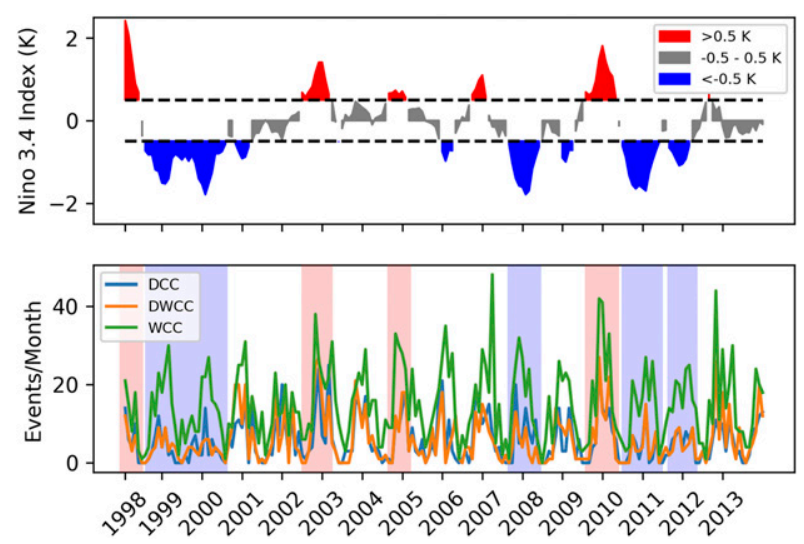

FIG. 3. (top) The Niño-3.4 index represents the temperature anomaly of the Niño-3.4 region. (bottom) DCC, DWCC, and WCC events per month within the primary study regions during the lifetime of TRMM, with color blocks representing the El Niño (red) and La Niña (blue) time periods, where the temperature anomalies last six months or longer. 

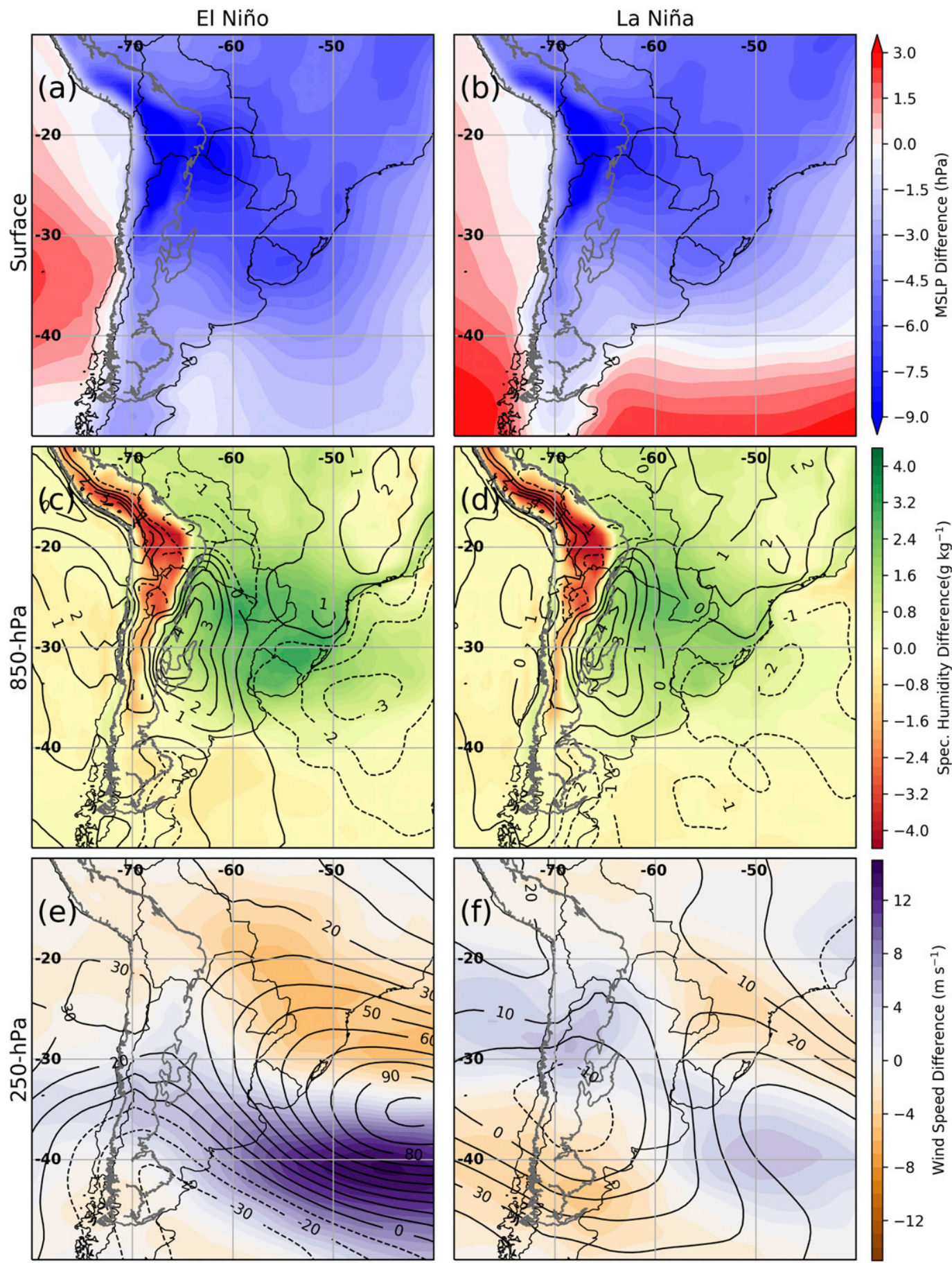

FIG. 4. The differences between convective day composites and climatology during austral spring (SON) are shown for (left) El Niño and (right) La Niña. Convection had to occur within the four primary study regions in subtropical South America. (a),(b) Differences in mean sea level pressure (MSLP), (c),(d) map differences in 850-hPa specific humidity (filled) and meridional wind speed (contoured), and (e),(f) differences in 250-hPa wind speed and geopotential height.

At the $850-\mathrm{hPa}$ pressure level, moisture increases by $1-1.5 \mathrm{~g} \mathrm{~kg}^{-1}$ over northern Argentina, Paraguay, Uruguay, and southern Brazil during spring El Niño convective days as compared to La Niña convective days
(Fig. 5b), while lesser increases in moisture are present on El Niño days during summer (Fig. 5e). Since flow is climatologically from the north (Figs. 2c,d), increases in meridional wind speed over Bolivia and Paraguay 

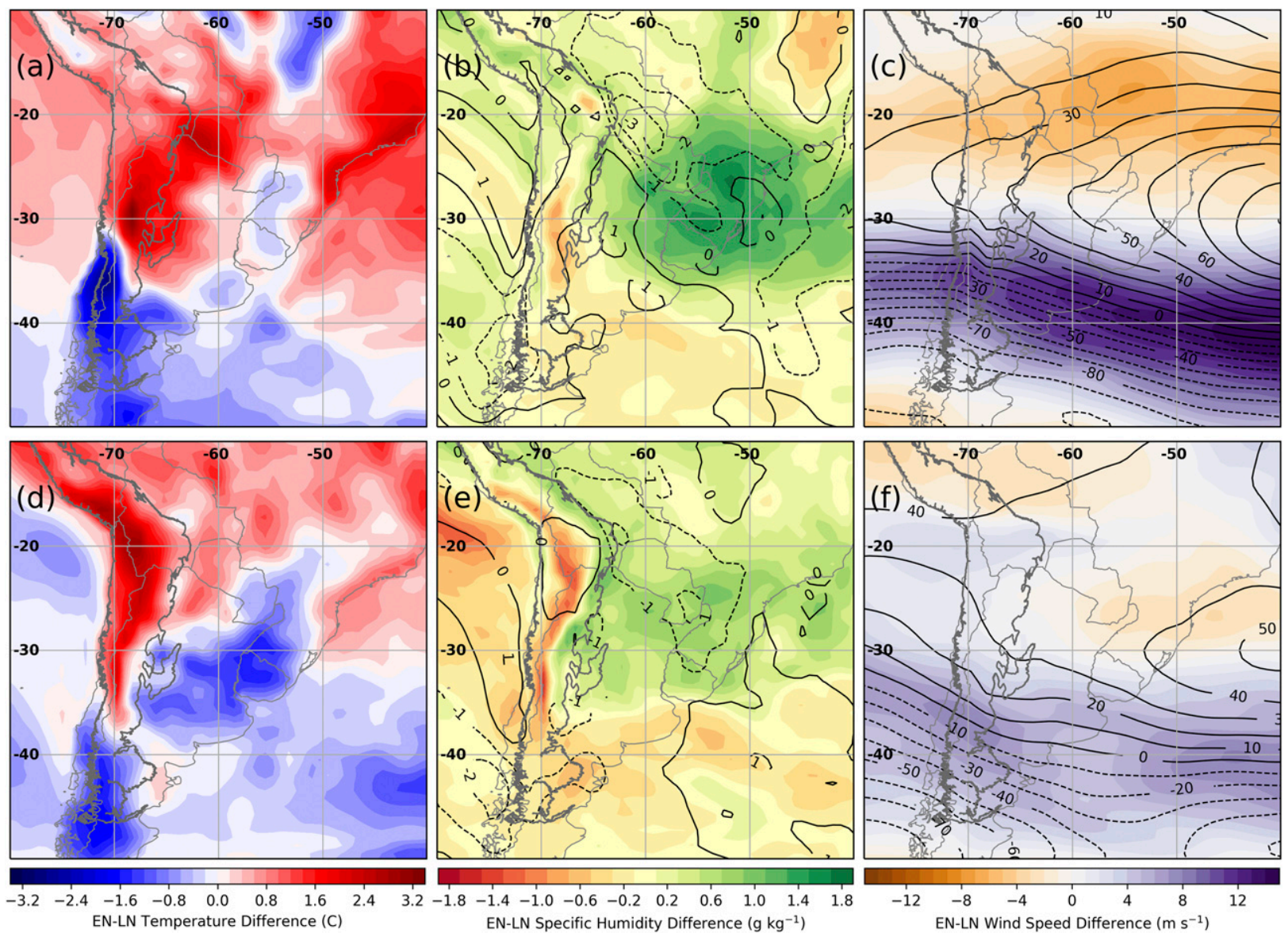

FIG. 5. The differences between El Niño and La Niña convective days during (a)-(c) austral spring (SON) and (d)-(f) summer (DJF) are plotted for multiple vertical levels. Convection had to occur within the four primary study regions in subtropical South America. (a),(d) Differences of 2-m temperature. (b),(e) Differences in 850-hPa specific humidity (filled) and meridional wind speed (contoured). (c),(f) Differences in 250-hPa wind speed (filled) and geopotential height (contoured).

indicate a strengthening of the SALLJ, especially during spring. Over the primary study regions in subtropical South America, any changes in the strength of the SALLJ are negligible. At upper levels, though, the jet stream substantially increases in strength during El Niño as compared to La Niña on spring convective days (Fig. 5c), with only moderate increases in jet speed on summer El Niño convective days. Additionally, during El Niño convective days of both seasons, there is a stronger upper-level trough moving onshore across southern South America with a ridge downstream. The equatorward entrance region of the jet, favored for rising motion due to divergence at jet level, is located directly over the primary study regions. This enhanced upper-level support increases rising motion, which when coupled with topographic forcing along the SDC and Andean foothills, helps to overcome convective inhibition and cause the initiation of intense storms. Overall, the enhanced low-level moisture and upper-level jet stream supports a more favorable environment for convection during El Niño compared to La Niña, especially during austral spring.

\section{b. Deep convective cores (DCCs)}

Modest variations in DCC frequency do occur in different regions between ENSO phases, but DCCs occur across all phases of ENSO within the primary study regions in subtropical South America (Fig. 3 and Table 2). The largest differences in DCC frequency between El Niño and La Niña is in the SDC and SE sectors during austral spring and summer, which are statistically significant at the $90 \%$ confidence interval (Table 3). The SDC sector is the most active area for intense deep convection in subtropical South America, especially during austral spring and summer (Rasmussen et al. 2016). The eastern sectors have smaller frequency differences between El Niño and La Niña (Table 3). 
TABLE 2. Total number of convective cores that occurred during an ENSO phase in a sector, divided seasonally into Sep-Nov $(\mathrm{SON}) / \mathrm{Dec}-\mathrm{Feb}(\mathrm{DJF})$.

\begin{tabular}{lrrrr}
\hline \hline & NW & SDC & NE & \multicolumn{1}{c}{ SE } \\
\hline El Niño & & & & \\
DCC & $16 / 13$ & $34 / 74$ & $18 / 12$ & $29 / 29$ \\
DWCC & $11 / 18$ & $26 / 76$ & $33 / 11$ & $54 / 36$ \\
WCC & $27 / 35$ & $30 / 62$ & $83 / 61$ & $79 / 88$ \\
Neutral & & & & \\
DCC & $51 / 31$ & $88 / 111$ & $36 / 32$ & $45 / 46$ \\
DWCC & $59 / 30$ & $61 / 106$ & $55 / 25$ & $83 / 58$ \\
WCC & $63 / 94$ & $77 / 151$ & $109 / 74$ & $158 / 160$ \\
La Niña & & & & \\
DCC & $19 / 12$ & $31 / 49$ & $21 / 16$ & $25 / 21$ \\
DWCC & $16 / 18$ & $24 / 26$ & $22 / 10$ & $20 / 26$ \\
WCC & $33 / 67$ & $57 / 107$ & $80 / 51$ & $89 / 109$ \\
\hline
\end{tabular}

Using volumetric rain rates for each TRMMidentified storm in this study, DCC storms produce similar amounts of rain between El Niño and La Niña (Fig. 6). None of the sectors have a statistically significant difference between El Niño and La Niña. These storms only account for approximately $6 \%$ of the annual precipitation in this sector (Rasmussen et al. 2016); therefore, DCCs are not likely to account for the ENSO precipitation anomalies (Figs. 2a,b). The increased rainfall rate in the Highlands sector during El Niño agrees with the findings of Grimm and Tedeschi (2009). The Amazon sector shows heavier rain rates during La Niña in austral spring, although the differences in rainfall rates are not statistically significant in this study.

One of the most substantial and statistically significant differences in DCCs between ENSO phases is in the maximum convective core height, calculated as the maximum height of the $40-\mathrm{dBZ}$ contiguous echo core. Across almost all seasons and sectors, El Niño DCCs are taller than La Niña DCCs (Fig. 7). The maximum height differences between ENSO phases are statistically significant at the $95 \%$ confidence interval during spring in all four sectors and during summer in the SDC sector. These differences indicate that more vigorous deep convection occurs during El Niño, as storms are frequently $1-2 \mathrm{~km}$ taller during El Niño than La Niña.

A useful tool in diagnosing storm characteristic differences between ENSO phases in the TRMM PR data is the CFAD diagram described in section 2. The entire storm that contains the DCC is analyzed, thus convective and stratiform rainfall is included in the CFAD results. The difference between the El Niño and La Niña convective CFADs confirms that El Niño DCCs have more robust and deeper convection, with a shift in the distribution of echoes toward higher reflectivities within El Niño DCCs (Fig. 8a). In the stratiform CFAD,
TABLE 3. Average number of the various convective cores that occurred during an ENSO-phase month in a sector, divided seasonally as in Table 2 .

\begin{tabular}{ccccc}
\hline \hline & NW & SDC & NE & SE \\
\hline El Niño & & & & \\
DCC & $0.53 / 0.43$ & $1.13 / 2.47$ & $0.60 / 0.40$ & $0.97 / 0.97$ \\
DWCC & $0.37 / 0.60$ & $0.87 / 2.53$ & $1.10 / 0.37$ & $1.80 / 1.20$ \\
WCC & $0.90 / 1.17$ & $1.00 / 2.07$ & $2.77 / 2.03$ & $2.63 / 2.93$ \\
Neutral & & & & \\
DCC & $0.47 / 0.29$ & $0.81 / 1.03$ & $0.33 / 0.30$ & $0.42 / 0.43$ \\
DWCC & $0.55 / 0.28$ & $0.56 / 0.98$ & $0.51 / 0.23$ & $0.77 / 0.54$ \\
WCC & $0.58 / 0.87$ & $0.71 / 1.40$ & $1.01 / 0.69$ & $1.46 / 1.48$ \\
La Niña & & & & \\
DCC & $0.35 / 0.22$ & $0.57 / 0.91$ & $0.39 / 0.30$ & $0.46 / 0.39$ \\
DWCC & $0.30 / 0.33$ & $0.44 / 0.48$ & $0.41 / 0.19$ & $0.37 / 0.48$ \\
WCC & $0.61 / 1.24$ & $1.06 / 1.98$ & $1.48 / 0.94$ & $1.65 / 2.02$ \\
\hline
\end{tabular}

enhanced stratiform precipitation below the melting level is evident during La Niña, with more frequent echoes near $40 \mathrm{dBZ}$ between $0-4 \mathrm{~km}$ (Fig. $8 \mathrm{~b}$ ). Given that the volumetric rain rates are fairly similar for both $\mathrm{El}$ Niño and $\mathrm{La}$ Niña DCCs (Fig. 6), the reduced convective intensity and increased stratiform intensity near the surface likely balances out and results in a fairly similar total rainfall amount, but from different types of precipitation echoes. This result is supported by additional analysis showing that the area of the stratiform precipitation is similar between ENSO phases (not shown).

ENSO also modifies the synoptic environment which supports deeper convective storms during El Niño (Figs. 4-5). While differences in the synoptic environment associated with El Niño and La Niña were discussed earlier, a more detailed look at changes to instability yields new insights. Convective available potential energy (CAPE) is often used as a forecasting metric to quantify potential storm intensity. ERA-Interim reanalysis composite differences between El Niño and La Niña show an increase in surface-based CAPE in all sectors during El Niño (Fig. 9). This enhanced thermodynamic support allows for deeper and stronger convection, with greater vertical motion throughout the storm. The greatest increase in CAPE during El Niño occurs when DCC storms are in the SE sector. When storms occur in the two western sectors, the maximum increase in CAPE is not centrally situated within their regions, but there is still a net increase in CAPE within each sector.

\section{c. Deep and wide convective cores (DWCCs)}

Deep and wide convective cores (DWCCs) occur in similar frequency as DCCs (Tables 2,3). DWCCs are most frequent within the southern sectors for all seasons and ENSO phases. During El Niño, DWCCs occur most frequently during austral summer in all sectors. 

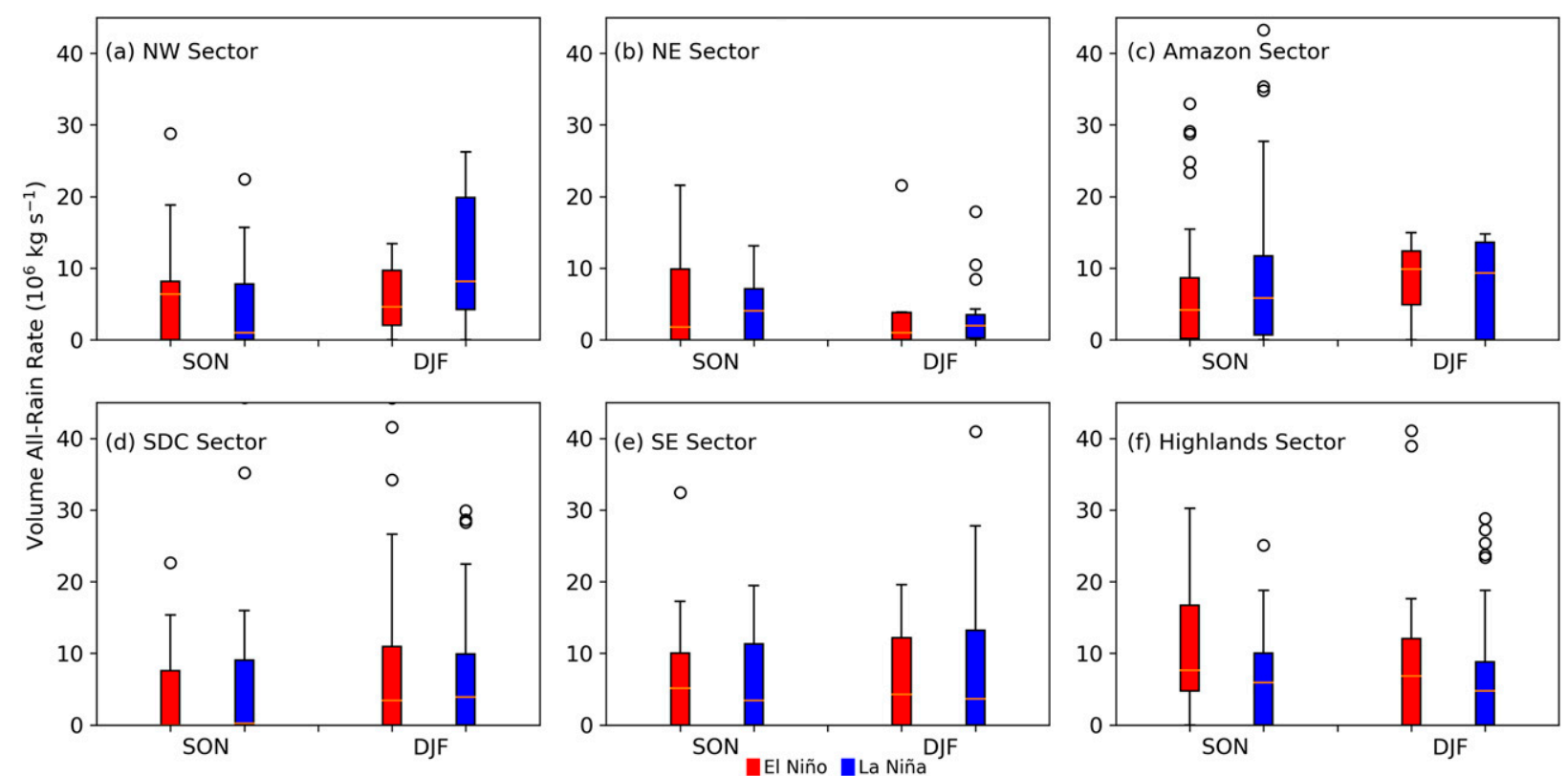

FIG. 6. DCC volumetric rainfall by ENSO phase and sector in austral spring (SON) and summer (DJF) in a typical box-and-whiskers plot, where the open circles represent outlying data points. Statistically significant differences between El Niño and La Niña at the $95 \%$ confidence interval are represented by the larger, hatched boxes.

Additionally, they are more frequent in the eastern sectors during El Niño than La Niña. These storms produce heavy rainfall, which causes flash and slow-rise flooding if they remain stationary for many hours.

The storm characteristics of DWCCs occurring during the two ENSO phases are compared in Figs. 10 and 11. Rainfall resulting from DWCCs is similar during
El Niño and La Niña phases, with the only statistically significant difference occurring in the NW sector during summer (Fig. 10). Similar to the results for the DCCs, DWCCs are also deeper during El Niño in the subtropical sectors across almost all seasons (Fig. 11). The height differences are statistically significant at the $95 \%$ confidence interval for the NW, SDC, and SE
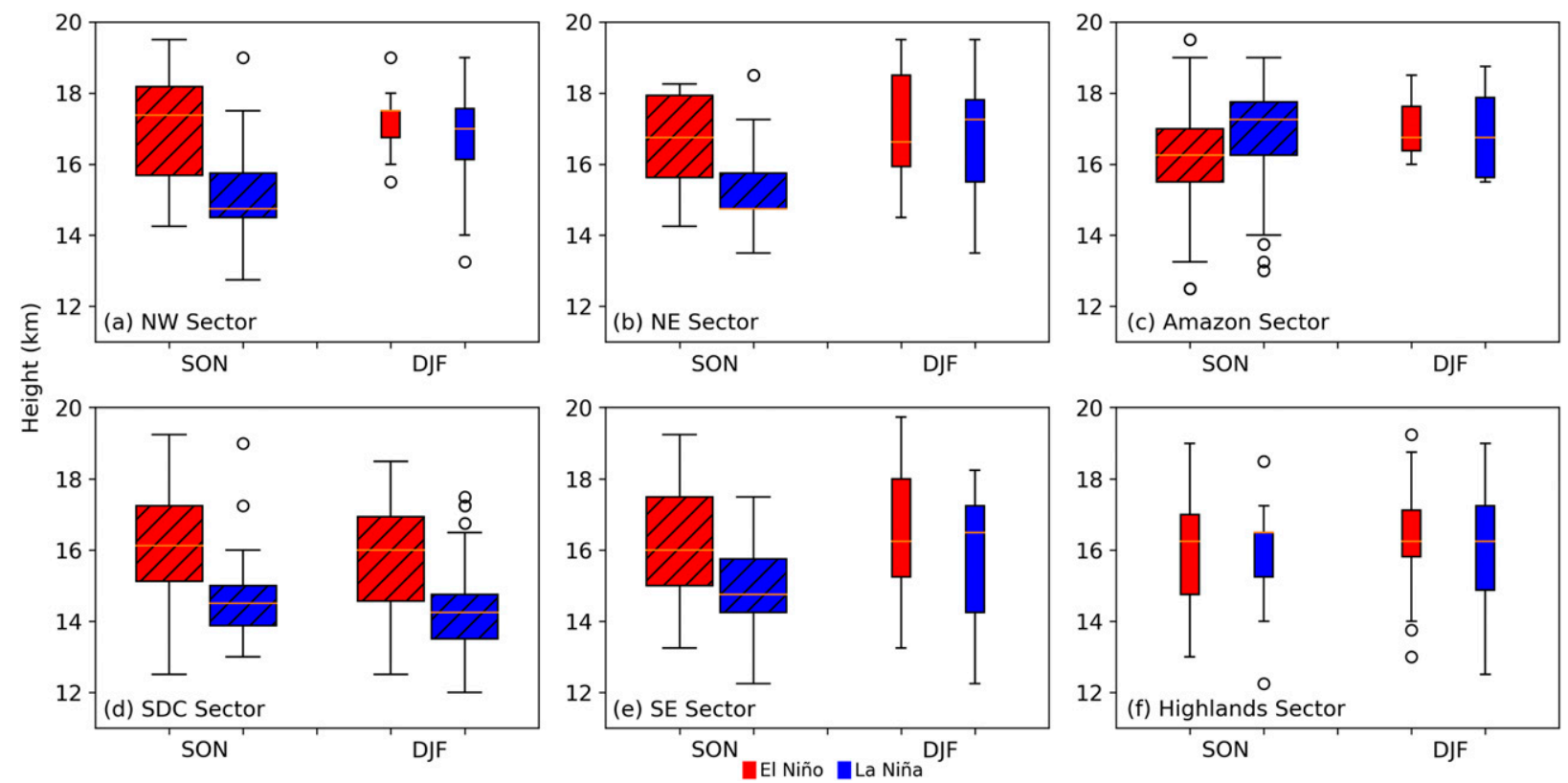

FIG. 7. As in Fig. 6, but for the maximum height of the contiguous convective core. 

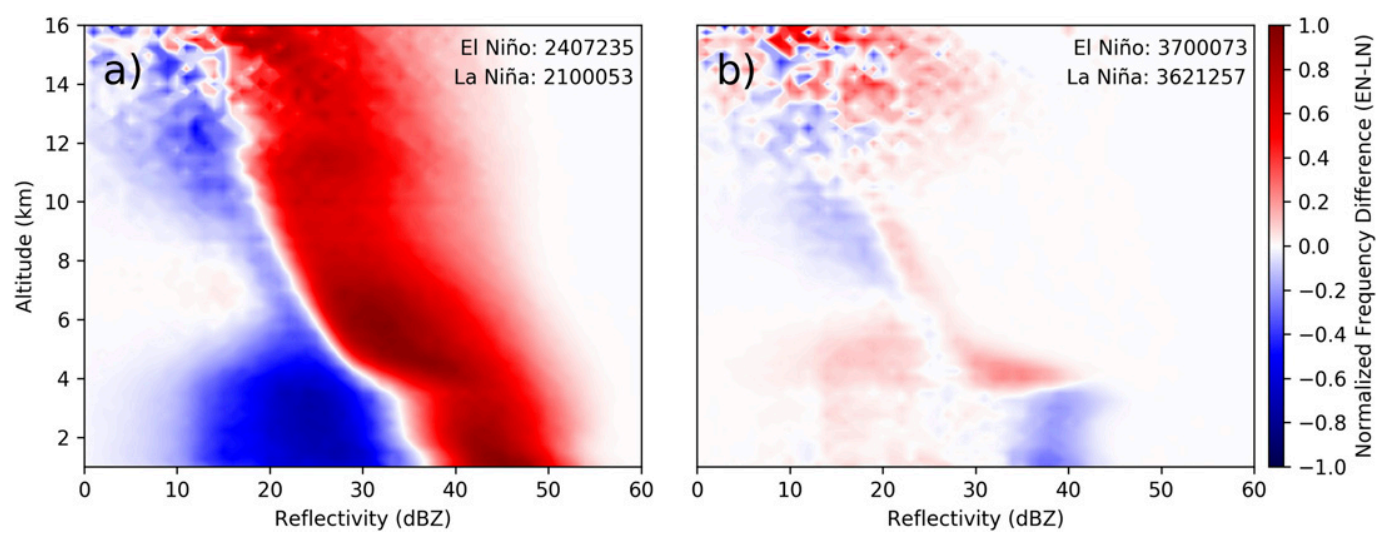

FIG. 8. Differences between El Niño and La Niña contoured frequency by altitude diagram (CFADs; Yuter and Houze 1995) for DCCs, separated by (a) convective and (b) stratiform rain with each vertical level normalized by the most frequent reflectivity bin within that level. Positive values represent an increase in frequency for storms during El Niño. The number of pixels that went into each composite is listed in the top right corner of each panel.

sectors during spring and NW and SDC sectors during summer. In the Amazon and Highlands sectors, the results are mixed due to limited numbers of storms in these areas.
The difference between the CFADs for DWCCs during El Niño periods and La Niña periods are shown in Fig. 12 for both the convective and stratiform components of the storms containing DWCCs.
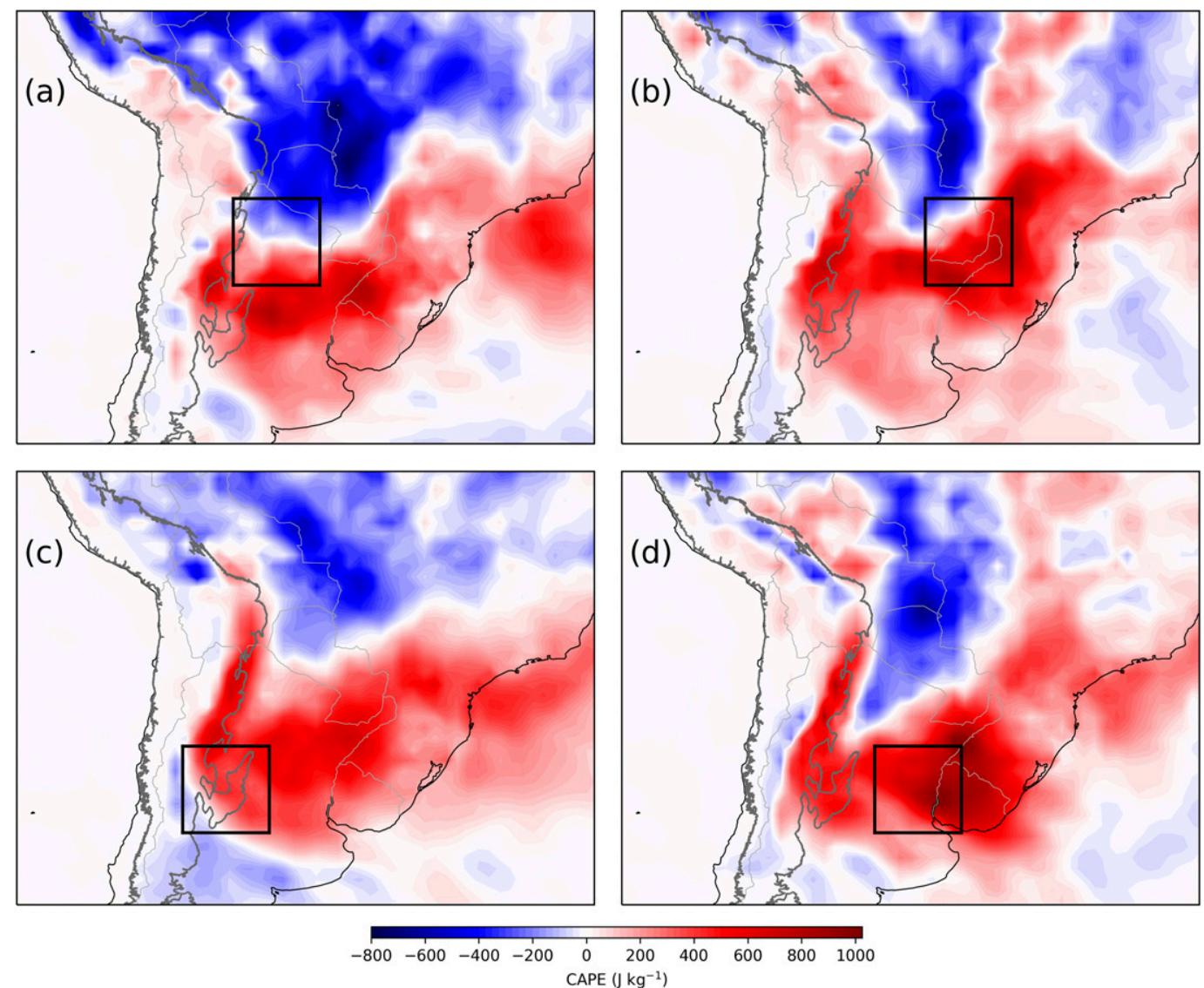

FIG. 9. Difference in SB-CAPE $\left(\mathrm{J} \mathrm{kg}^{-1}\right)$ between El Niño and La Niña for days with storms in each of the sectors outlined in black. 

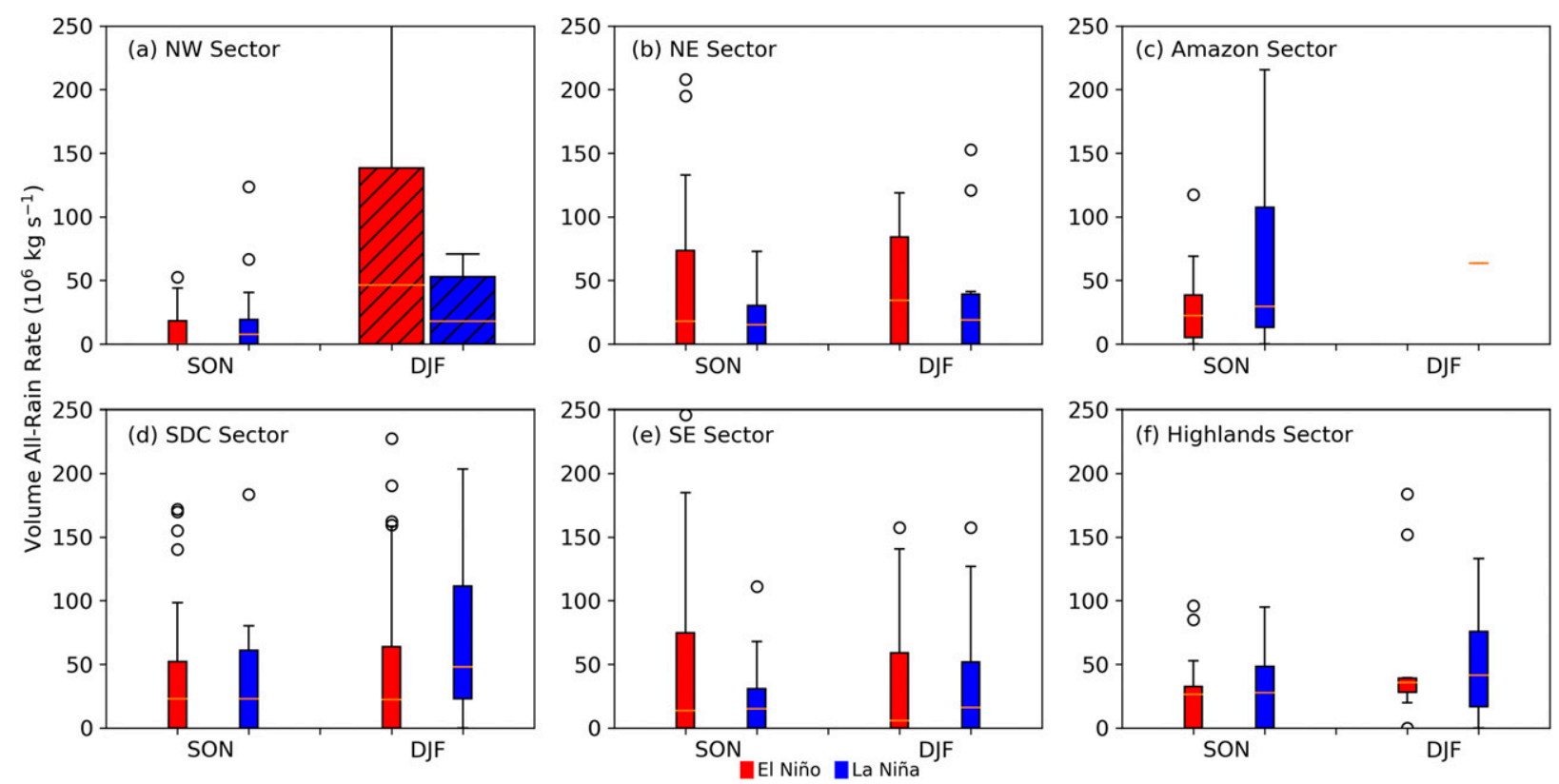

FIG. 10. As in Fig. 6, but for the rainfall rates found in DWCCs.

The convective difference CFAD shows a strong shift toward higher reflectivity at all levels during El Niño periods, indicating more intense convection throughout the entire depth of the storm (Fig. 12a). Combined with the taller height of the $40-\mathrm{dB} Z$ core shown previously (Fig. 8), DWCCs appear to be more intense during El Niño. Within the stratiform region of El Niño DWCCs, there is a shift to higher reflectivities above the bright band at $4 \mathrm{~km}$ which indicates enhanced stratiform precipitation aloft (Fig. 12b). However, below the bright band, La Niña DWCC storms have higher reflectivities than El Niño DWCCs.

As was seen for DCC storms (Fig. 9), these deeper and stronger DWCC storms have as much as 500 $700 \mathrm{~J} \mathrm{~kg}^{-1}$ higher values of CAPE during El Niño
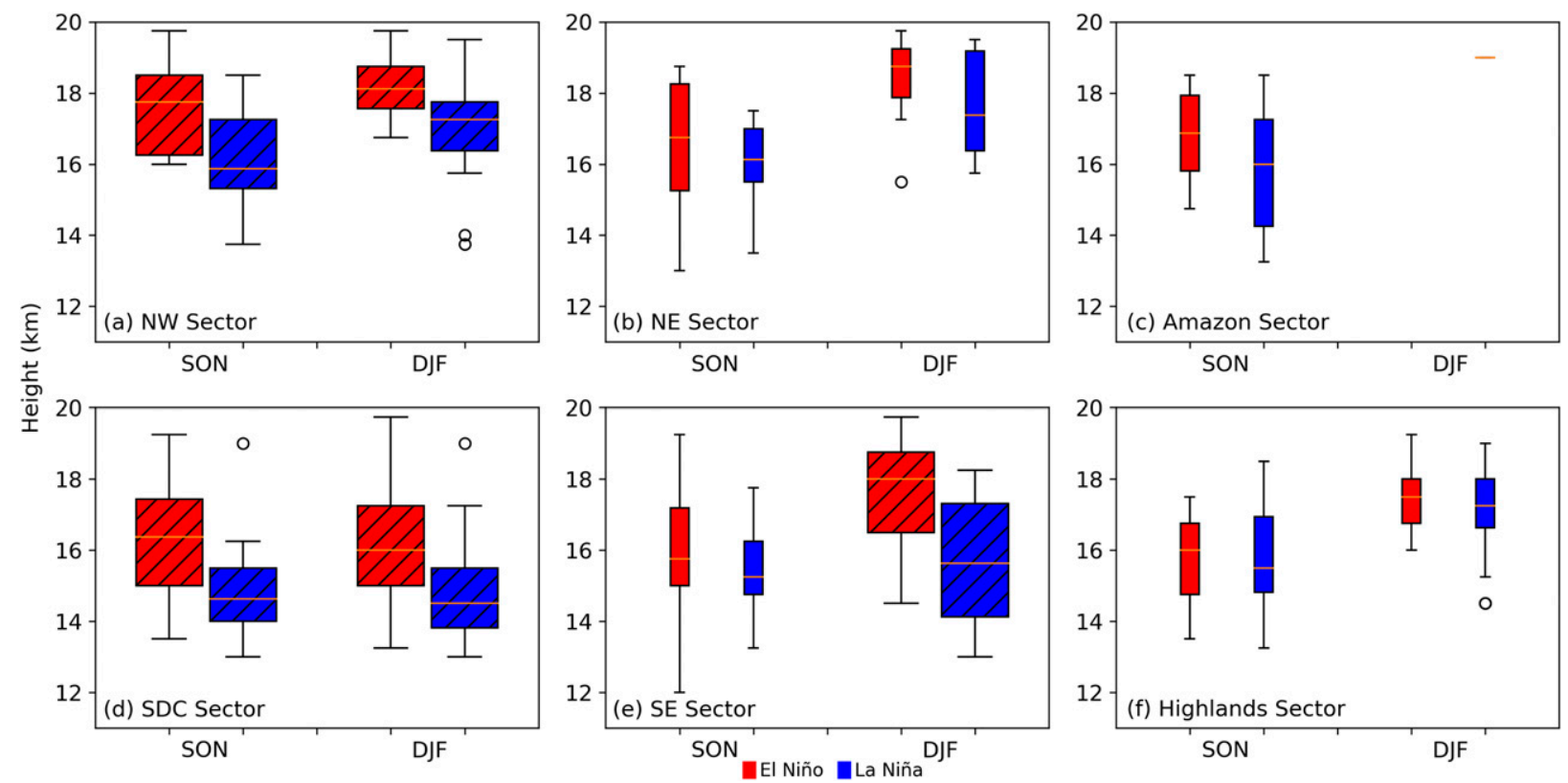

FIG. 11. As in Fig. 7, but for the maximum height of DWCCs. 

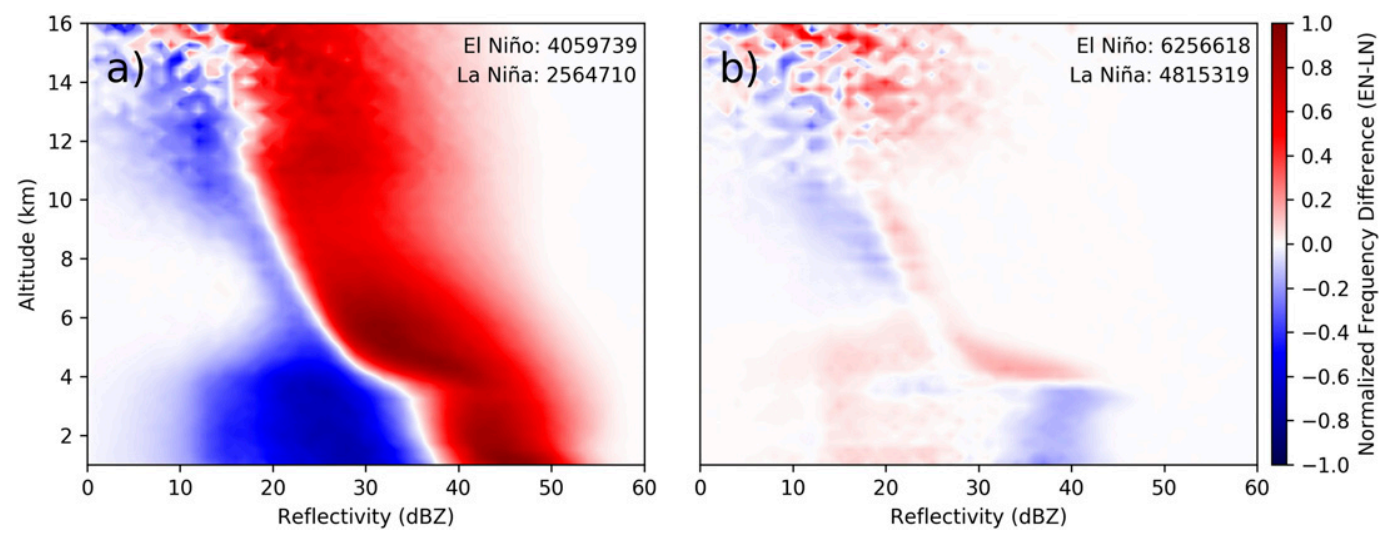

FIG. 12. As in Fig. 8, but for CFADs of DWCCs.

compared to La Niña (Fig. 13). No matter which sector the DWCC storm occurs in, there is an increase in CAPE during El Niño along the Andean foothills and SDC. These increases in instability would support convective initiation over the topography once any capping inversion is broken (Rasmussen and Houze 2016).

\section{d. Wide convective cores (WCCs)}

Wide convective cores (WCCs), which represent upscale-organized and mature MCSs capable of producing heavy rainfall and flooding (Houze et al. 2007; Rasmussen and Houze 2011), are the most frequent type of intense convection in all study regions and seasons (Tables 2 and 3). The two eastern sectors have the
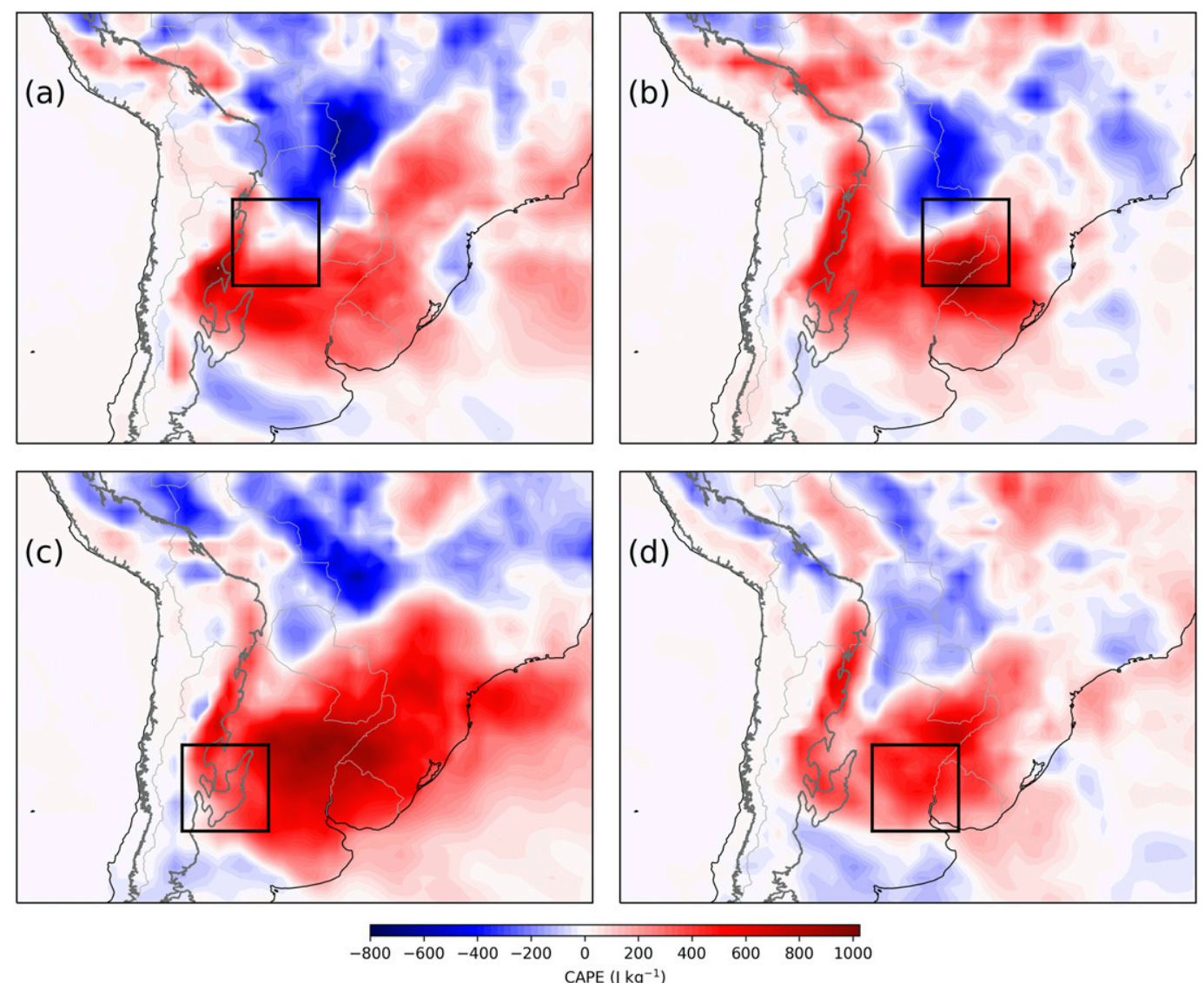

FIG. 13. As in Fig. 9, but for CAPE on days with DWCCs. 

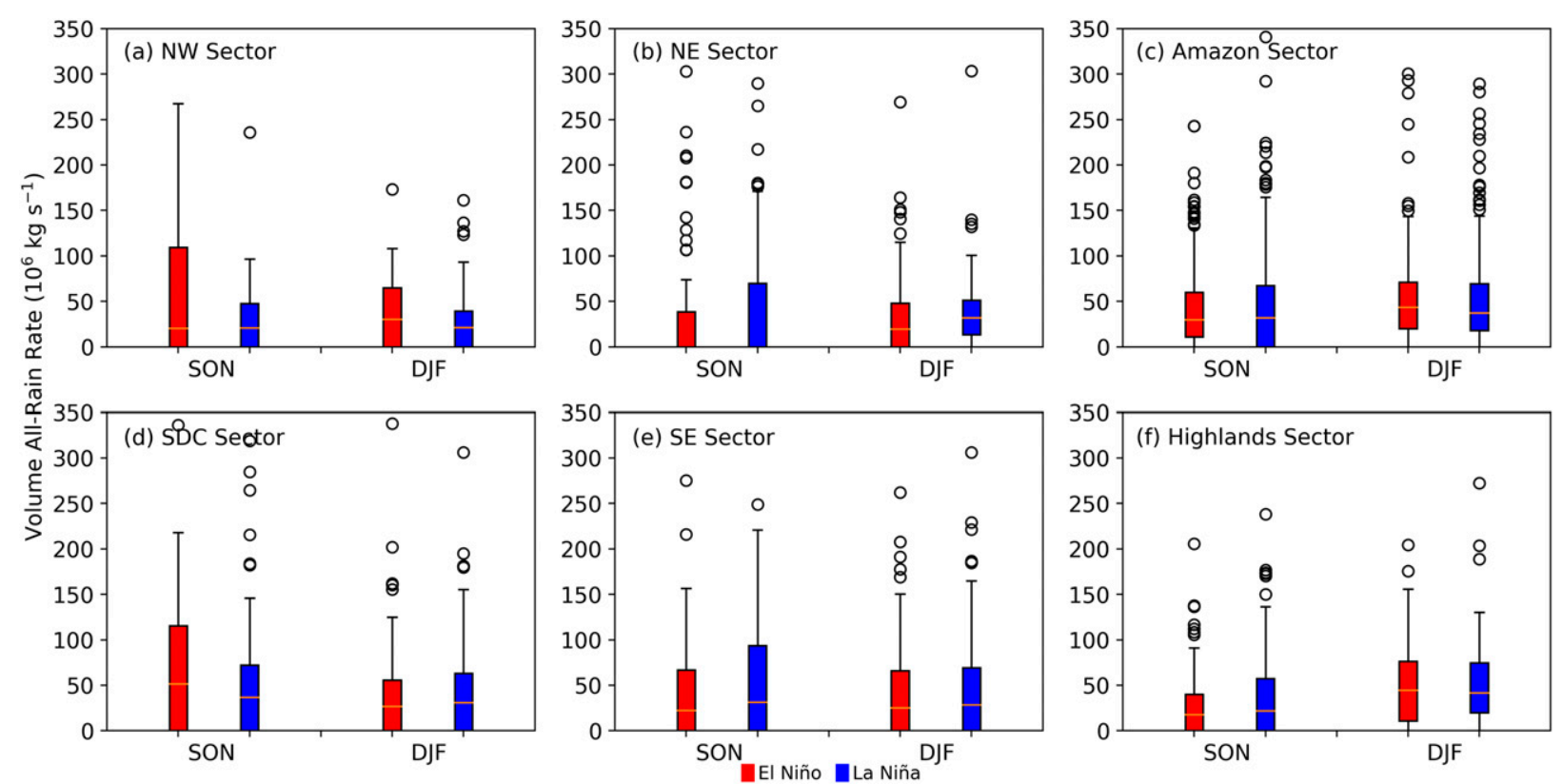

FIG. 14. As in Fig. 6, but for rainfall rates found in WCCs.

highest frequency of WCC occurrence for all ENSO phases due to the tendency for storms to grow upscale as they move eastward following initiation (Romatschke et al. 2010; Rasmussen and Houze 2011, 2016). With respect to ENSO, WCCs are more frequent during La Niña in all sectors and seasons, with the exception of the NE sector during austral summer. The SE sector generally has the greatest frequency of WCCs (Table 3), and the differences in frequency in this sector between El Niño and La Niña are statistically significant at the $90 \%$ confidence interval. In the western sectors, WCCs are most common during austral summer (Tables 2, 3).

The mean volumetric rainfall rates appear almost identical between ENSO phases for all sectors, with no statistically significant differences (Fig. 14). Therefore, if a WCC occurs, it likely produces similar volumetric rainfall rates regardless of the ENSO phase. Storm duration is not analyzed in this study due to the nature of the TRMM satellite's orbit in capturing storm snapshots; therefore, total rainfall amounts and the climatological rainfall anomalies cannot be analyzed from this perspective. It is possible that changes in storm duration, broad stratiform regions (Houze et al. 2007), or nonextreme precipitation differences between ENSO phases may account for the climatological rainfall anomalies (Figs. 2a,b), but is beyond the scope of the current study.

Examining the maximum height of the convective core, El Niño WCCs tend to be taller than La Niña WCCs, especially in the NE and SDC sectors (Fig. 15), but the magnitude of the difference is usually less than one kilometer. The differences are statistically significant at the
$95 \%$ confidence interval during spring and summer in all subtropical sectors except for the SDC sector during spring and the NW sector during summer. Since all three categories of intense convection are deeper during El Niño, this appears to be a systematic difference in convection during the warm phase of ENSO.

Increased frequencies of higher reflectivities during El Niño is apparent in the convective CFAD, indicating that WCCs contain more frequent strong convection during El Niño compared to La Niña (Fig. 16a). The bright band does not appear to be stronger during a particular ENSO phase in the stratiform CFAD (Fig. 16b). As a result, there are minimal differences in the stratiform structure of WCCs between ENSO phases. Therefore, it appears that once a storm has grown upscale into a WCC, rainfall intensities are similar in El Niño and La Niña conditions.

The analysis of thermodynamic conditions for WCCs helps explain why they tend to be deeper and contain stronger convection. Surface-based CAPE is greater in all sectors during El Niño than La Niña, although the magnitude is small (100-300 $\mathrm{J} \mathrm{kg}^{-1}$; Fig. 17). Greater CAPE would support enhanced updraft speeds and more convective initiation once any convective inhibition is removed.

\section{e. Summary}

Overall, DCCs, DWCCs, and WCCs tend to be deeper and contain stronger convection during El Niño compared to La Niña. Increased CAPE and favorable placement of the equatorward entrance region of the 

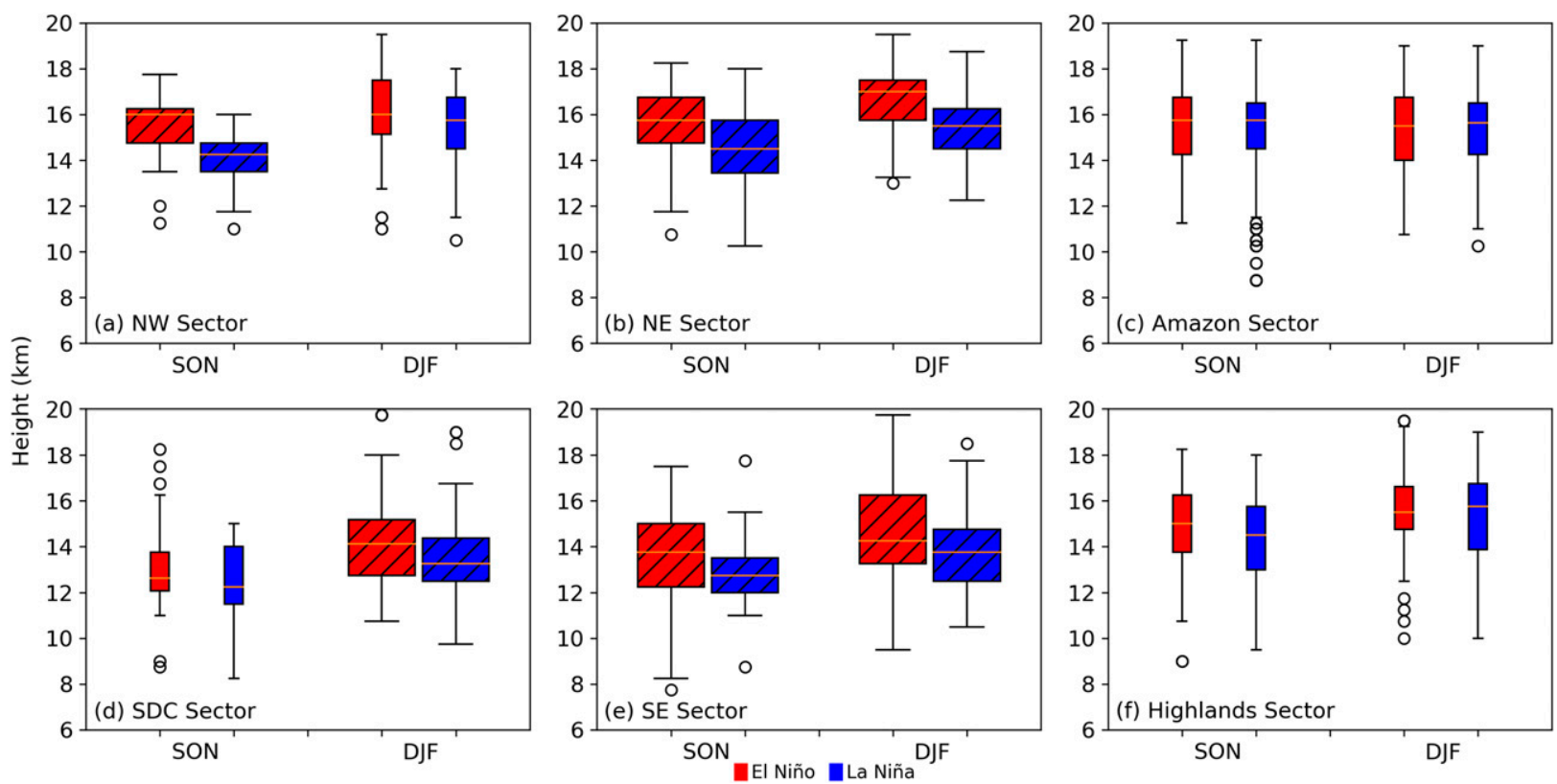

FIG. 15. As in Fig. 7, but for the maximum height of WCCs.

jet stream support these stronger storms. While more rain falls in the eastern sectors climatologically during El Niño, this study found similar rainfall rates between ENSO phases from these intense convective storms. With stronger storms occurring during El Niño, more hazardous weather may occur, such as hail and high winds. However, storm frequency does not vary greatly, and subtropical South America is likely to see DCCs, DWCCs, and WCCs in all phases of ENSO with varying storm characteristics.

\section{Conclusions}

Convection is an important component of Earth's climate; thus, it is critical to understand how large-scale atmospheric variability affects the frequency and intensity of convection. The variability of convection causes hydrologic extremes, such as flash flooding and drought, and modulate the frequency of severe weather. This study examines how ENSO conditions influences the frequency and characteristics of extreme convective storms in subtropical South America using a 16-yr TRMM PR dataset and ERA-Interim.

While previous research found that El Niño may suppress convection over tropical South America (Liebmann and Marengo 2001; Espinoza Villar et al. 2009; Shimizu et al. 2017), this study found that different phases of ENSO did not significantly promote or inhibit intense convection in the lee of the Andes Mountains, but more importantly modulated its frequency and
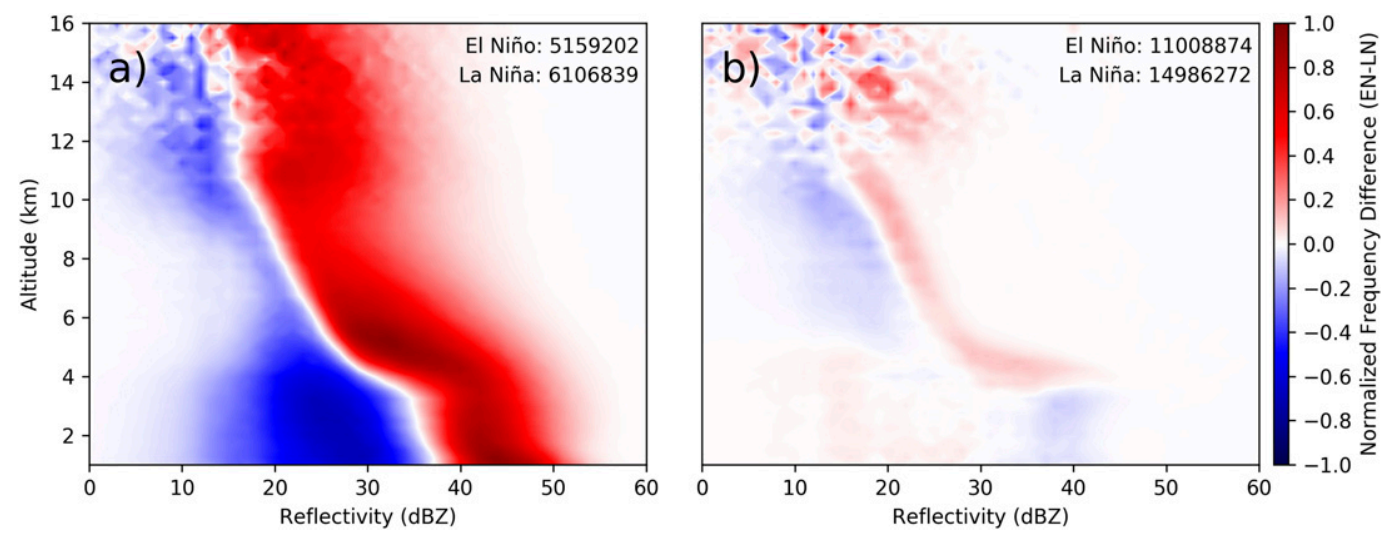

FIG. 16. As in Fig. 8, but for CFADs of WCCs. 

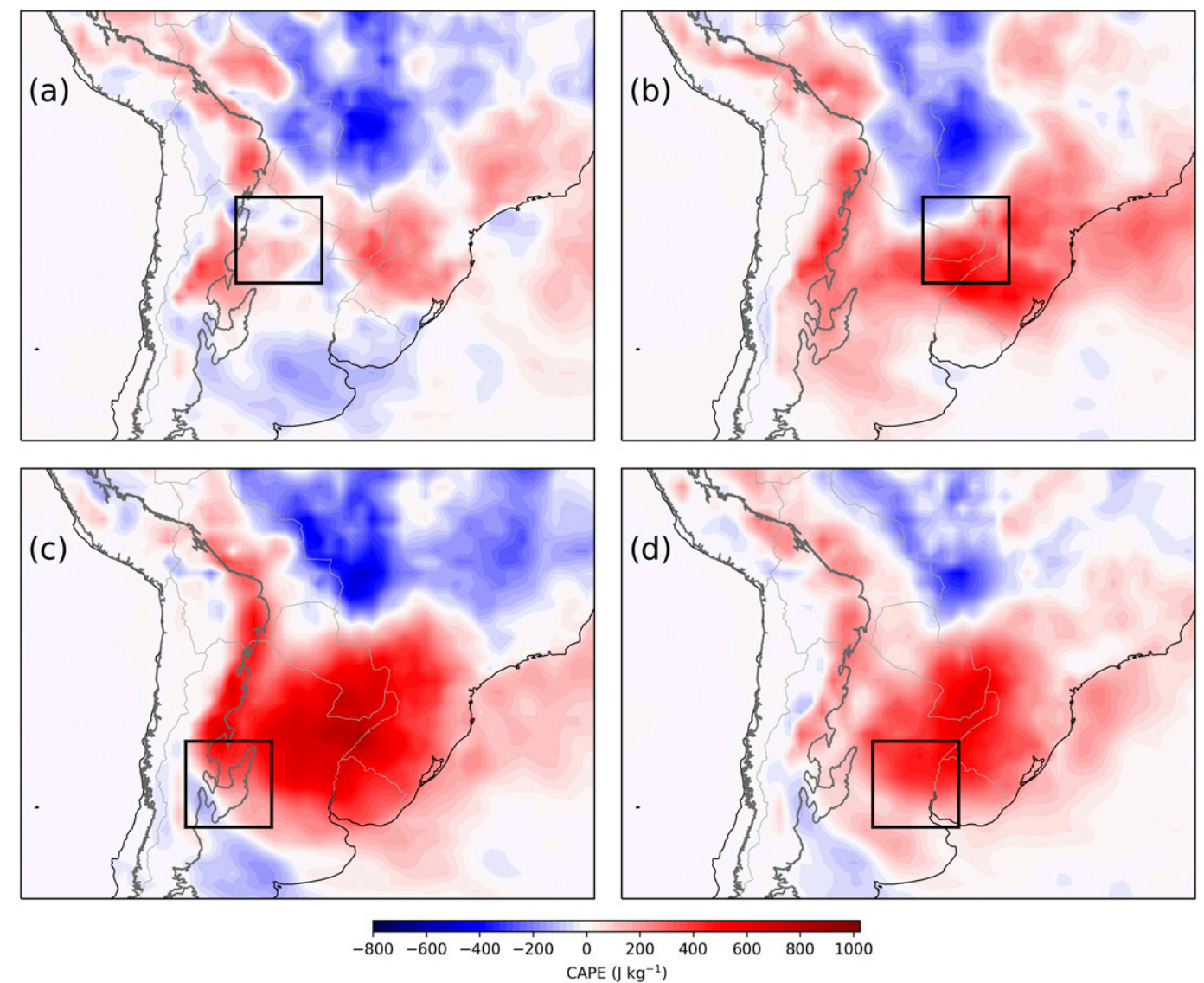

FIG. 17. As in Fig. 9, but for CAPE on days with WCCs.

strength. Deep convective storms (DCCs) tend to be more common during El Niño near the terrain in the foothills of western Argentina in austral spring and summer, while wide convective cores (WCCs) tend to be more frequent during La Niña in most sectors and seasons. Although this study found that rainfall increases during El Niño in the eastern subtropics of South America, the cause of these anomalies is not analyzed in this study. Changes in storm frequency and duration, along with changes to nonextreme precipitation, may explain the climatological ENSO precipitation anomalies and will be analyzed in future work. This study also does not explain why there is an increased frequency of WCCs during La Niña and may be the focus of a future study.

During El Niño, intense convective storms tend to be taller and contain more intense convective precipitation aloft than storms during La Niña. However, La Niña DCCs and DWCCs have enhanced stratiform reflectivities below the melting level, leading to more intense rainfall within those regions of the storms. Synoptic support for taller and more intense DCCs, DWCCs, and WCCs during El Niño likely comes from enhanced CAPE and favorable placement of the equatorward entrance region of the jet stream, which supports vertical motion through its secondary circulation. More moisture is also available to these storms within the primary study regions in subtropical South America. Overall, these enhanced synoptic conditions for convection are similar to the climatological changes in the synoptic environment that occur during El Niño (Fig. 4).

The results herein demonstrate that subtropical South America supports convection in any phase of ENSO and that the variability of extreme convection within this region does not appear to be strongly correlated to ENSO, unlike some other regions of the world. Therefore, seasonal-to-subseasonal forecasting of subtropical South American convection based on ENSO phases is unlikely to improve upon climatological forecasts. Small variations between phases cause intense convection to be stronger or weaker at different times, but the variability of high-impact severe weather hazards between ENSO phases, such as large hail or flooding, is beyond the scope of the current study. Finally, these results show that the economic sectors most at risk from hazardous convective storms do not realize a reprieve from strong 
convection during a particular ENSO phase, but may experience rainfall extremes from weaker precipitating systems depending on the phase.

Acknowledgments. The authors thank two anonymous reviewers for their comments and suggestions, which greatly improved the manuscript. This research was sponsored by National Science Foundation Grants AGS-1661657 and AGS-1661768, and an American Meteorological Society/NASA Earth Science Graduate Fellowship.

\section{REFERENCES}

Allen, J. T., M. K. Tippett, and A. H. Sobel, 2015: Influence of the El Niño/Southern Oscillation on tornado and hail frequency in the United States. Nat. Geosci., 8, 278-283, https://doi.org/ $10.1038 /$ ngeo2385.

Anderson, C. J., and R. W. Arritt, 2001: Mesoscale convective systems over the United States during the 1997-98 El Niño. Mon. Wea. Rev., 129, 2443-2457, https://doi.org/10.1175/15200493(2001)129<2443:MCSOTU>2.0.CO;2.

Arkin, P. A., 1982: The relationship between interannual variability in the $200 \mathrm{mb}$ tropical wind field and the Southern Oscillation. Mon. Wea. Rev., 110, 1393-1404, https://doi.org/ 10.1175/1520-0493(1982)110<1393:TRBIVI>2.0.CO;2.

Awaka, J., T. Iguchi, H. Kumagai, and K. Okamoto, 1997: Rain type classification algorithm for TRMM precipitation radar. Proc. Remote Sensing-A Scientific Vision for Sustainable Development (IGARSS'97), 1997 IEEE Int. Geoscience and Remote Sensing Symp., Vol. 4, Singapore, IEEE International, 1633-1635, https://doi.org/10.1109/IGARSS.1997.608993.

Bjerknes, J., 1969: Atmospheric teleconnections from the equatorial Pacific. Mon. Wea. Rev., 97, 163-172, https://doi.org/ 10.1175/1520-0493(1969)097<0163:ATFTEP>2.3.CO;2.

Blamey, R. C., C. Middleton, C. Lennard, and C. J. C. Reason, 2017: A climatology of potential severe convective environments across South Africa. Climate Dyn., 49, 2161-2178, https://doi.org/10.1007/s00382-016-3434-7.

Camilloni, I. A., and V. R. Barros, 2003: Extreme discharge events in the Parana River and their climate forcing. J. Hydrol., 278, 94-106, https://doi.org/10.1016/S0022-1694(03)00133-1.

Cavalcanti, I. F. A., and Coauthors, 2015: Precipitation extremes over La Plata Basin-Review and new results from observations and climate simulations. J. Hydrol., 523, 211-230, https:// doi.org/10.1016/j.jhydrol.2015.01.028.

Chronis, T. G., S. J. Goodman, D. Cecil, D. Buechler, F. J. Robertson, J. Pittman, and R. J. Blakeslee, 2008: Global lightning activity from the ENSO perspective. Geophys. Res. Lett., 35, L19804, https://doi.org/10.1029/2008GL034321.

Cook, A. R., and J. T. Schaefer, 2008: The relation of El Niño-Southern Oscillation (ENSO) to winter tornado outbreaks. Mon. Wea. Rev., 136, 3121-3137, https://doi.org/10.1175/2007MWR2171.1.

—, L. M. Leslie, D. B. Parsons, and J. T. Schaefer, 2017: The impact of El Niño-Southern Oscillation (ENSO) on winter and early spring U.S. tornado outbreaks. J. Appl. Meteor. Climatol., 56, 2455-2478, https://doi.org/10.1175/JAMC-D-16-0249.1.

Dai, A., 2001: Global precipitation and thunderstorm frequencies. Part I: Seasonal and interannual variations. J. Climate, 14, 1092-1111, https://doi.org/10.1175/1520-0442(2001)014<1092: GPATFP $>2.0 . \mathrm{CO} ; 2$.
Dee, D. P., and Coauthors, 2011: The ERA-Interim reanalysis: Configuration and performance of the data assimilation system. Quart. J. Roy. Meteor. Soc., 137, 553-597, https://doi.org/ 10.1002/qj.828.

Durkee, J. D., T. L. Mote, and J. M. Shepherd, 2009: The contribution of mesoscale convective complexes to rainfall across subtropical South America. J. Climate, 22, 4590-4605, https:// doi.org/10.1175/2009JCLI2858.1.

Espinoza Villar, J. C., and Coauthors, 2009: Spatio-temporal rainfall variability in the Amazon basin countries (Brazil, Peru, Bolivia, Colombia, and Ecuador). Int. J. Climatol., 29, 1574-1594, https://doi.org/10.1002/joc.1791.

Gonzalez, M. H., E. M. Garbarini, A. L. Rolla, and S. Eslamian, 2017: Meteorological drought indices: Rainfall prediction in Argentina. Handbook of Drought and Water Scarcity, Vol. 1: Principles of Drought and Water Scarcity, S. Eslamian and F. A. Eslamian, Eds., Taylor and Francis 541-570.

Grimm, A. M., and T. Ambrizzi, 2009: Teleconnections into South America from the tropics and extratropics on interannual and intraseasonal timescales. Past Climate Variability in South America and Surrounding Regions: From the Last Glacial Maximum to the Holocene, F. Vimeux, F. Sylvestre, and M. Khodri, Eds., Developments in Paleoenvironmental Research, Springer, 159-191 https://doi.org/10.1007/978-90-4812672-9_7.

__ and R. G. Tedeschi, 2009: ENSO and extreme rainfall events in South America. J. Climate, 22, 1589-1609, https://doi.org/ 10.1175/2008JCLI2429.1.

— , V. R. Barros, and M. E. Doyle, 2000: Climate variability in southern South America associated with El Niño and La Niña events. J. Climate, 13, 35-58, https://doi.org/10.1175/15200442(2000)013<0035:CVISSA > 2.0.CO;2.

Halpert, M. S., and C. F. Ropelewski, 1992: Surface temperature patterns associated with the Southern Oscillation. J. Climate, 5, 577-593, https://doi.org/10.1175/1520-0442(1992)005<0577: STPAWT $>2.0 . \mathrm{CO} ; 2$.

Hendon, H. H., 2003: Indonesian rainfall variability: Impacts of ENSO and local air-sea interaction. J. Climate, 16, 1775-1790, https://doi.org/10.1175/1520-0442(2003)016<1775: IRVIOE $>2.0 . \mathrm{CO} ; 2$.

Horel, J. D., and J. M. Wallace, 1981: Planetary-scale atmospheric phenomena associated with the Southern Oscillation. Mon. Wea. Rev., 109, 813-829, https://doi.org/10.1175/15200493(1981)109<0813:PSAPAW >2.0.CO;2.

Houze, R. A., Jr., 2004: Mesoscale convective systems. Rev. Geophys., 42, RG4003, https://doi.org/10.1029/2004RG000150.

_ D. C. Wilton, and B. F. Smull, 2007: Monsoon convection in the Himalayan region as seen by the TRMM Precipitation Radar. Quart. J. Roy. Meteor. Soc., 133, 1389-1411, https:// doi.org/10.1002/qj.106.

— K. L. Rasmussen, M. D. Zuluaga, and S. R. Brodzik, 2015: The variable nature of convection in the tropics and subtropics: A legacy of 16 years of the Tropical Rainfall Measuring Mission satellite. Rev. Geophys., 53, 994-1021, https:/ doi.org/10.1002/2015RG000488.

Huffman, G. J., and Coauthors, 2007: The TRMM Multisatellite Precipitation Analysis (TMPA): Quasi-global, multiyear, combined-sensor precipitation estimates at fine scales. J. Hydrometeor., 8, 38-55, https://doi.org/10.1175/JHM560.1.

Iguchi, T., T. Kozu, R. Meneghini, J. Awaka, and K. Okamoto, 2000: Rain-profiling algorithm for the TRMM Precipitation Radar. J. Appl. Meteor., 39, 2038-2052, https://doi.org/ 10.1175/1520-0450(2001)040<2038:RPAFTT>2.0.CO;2. 
- — - J. Kwiatkowski, R. Meneghini, J. Awaka, and K. Okamoto, 2009: Uncertainties in the rain profiling algorithm for the TRMM Precipitation Radar. J. Meteor. Soc. Japan, 87A, 1-30, https://doi.org/10.2151/jmsj.87A.1.

Karoly, D. J., 1989: Southern Hemisphere circulation features associated with El Niño-Southern Oscillation events. J. Climate, 2, 1239-1252, https://doi.org/10.1175/1520-0442(1989)002<1239: SHCFAW $>2.0 . C O ; 2$.

Karyampudi, V. M., M. L. Kaplan, S. E. Koch, and R. J. Zamora, 1995: The influence of the Rocky Mountain on the 13-14 April 1986 severe weather outbreak. Part I: Mesoscale lee cyclogenesis and its relationship to severe weather and dust storms. Mon. Wea. Rev., 123, 1394-1422, https://doi.org/10.1175/15200493(1995)123<1394:TIOTRM>2.0.CO;2.

Kousky, V. E., M. T. Kagano, and I. F. A. Cavalcanti, 1984: A review of the Southern Oscillation: Oceanic-atmospheric circulation changes and related rainfall anomalies. Tellus, 36A, 490-504, https://doi.org/10.1111/j.1600-0870.1984.tb00264.x.

Kummerow, C., W. Barnes, T. Kozu, J. Shiue, and J. Simpson, 1998: The Tropical Rainfall Measuring Mission (TRMM) sensor package. J. Atmos. Oceanic Technol., 15, 809-817, https://doi.org/ 10.1175/1520-0426(1998)015<0809:TTRMMT>2.0.CO;2.

— , and Coauthors, 2000: The status of the Tropical Rainfall Measuring Mission (TRMM) after two years in orbit. J. Appl. Meteor., 39, 1965-1982, https://doi.org/10.1175/1520-0450(2001) 040<1965:TSOTTR $>2.0$.CO;2.

Lee, S.-K., B. E. Mapes, C. Wang, D. B. Enfield, and S. J. Weaver, 2014: Springtime ENSO phase evolution and its relation to rainfall in the continental U.S. Geophys. Res. Lett., 41, 16731680, https://doi.org/10.1002/2013GL059137.

Lichtenstein, E. R., 1980: La depresión del Noroeste argentino. Facultad de Ciencias Exactas y Naturales. Universidad de Buenos Aires, 137 pp., https:/digital.bl.fcen.uba.ar/download/ tesis/tesis_n1649_Lichtenstein.pdf.

Liebmann, B., and J. A. Marengo, 2001: Interannual variability of the rainy season and rainfall in the Brazilian Amazon Basin. J. Climate, 14, 4308-4318, https://doi.org/10.1175/1520-0442(2001) 014<4308:IVOTRS $>2.0$. CO;2.

Parhi, P., A. Giannini, P. Gentine, and U. Lall, 2016: Resolving contrasting regional rainfall responses to El Niño over tropical Africa. J. Climate, 29, 1461-1476, https://doi.org/10.1175/ JCLI-D-15-0071.1.

Qie, X., X. Wu, T. Yuan, J. Bian, and D. Lu, 2014: Comprehensive pattern of deep convective systems over the Tibetan PlateauSouth Asian monsoon region based on TRMM data. J. Climate, 27, 6612-6626, https://doi.org/10.1175/JCLI-D-14-00076.1.

Rasmussen, K. L., and R. A. Houze, 2011: Orogenic convection in subtropical South America as seen by the TRMM satellite. Mon. Wea. Rev., 139, 2399-2420, https://doi.org/10.1175/ MWR-D-10-05006.1.

— , and - 2016: Convective initiation near the Andes in subtropical South America. Mon. Wea. Rev., 144, 2351-2374, https://doi.org/10.1175/MWR-D-15-0058.1.

_ S. L. Choi, M. D. Zuluaga, and R. A. Houze, 2013: TRMM precipitation bias in extreme storms in South America. Geophys. Res. Lett., 40, 3457-3461, https://doi.org/10.1002/grl.50651.

_ - M. D. Zuluaga, and R. A. Houze, 2014: Severe convection and lightning in subtropical South America. Geophys. Res. Lett., 41, 7359-7366, https://doi.org/10.1002/2014GL061767.

, M. M. Chaplin, M. D. Zuluaga, and R. A. Houze, 2016: Contribution of extreme convective storms to rainfall in South America. J. Hydrometeor., 17, 353-367, https://doi.org/ 10.1175/JHM-D-15-0067.1.
Rasmusson, E. M., and T. H. Carpenter, 1983: The relationship between eastern equatorial Pacific sea surface temperatures and rainfall over India and Sri Lanka. Mon. Wea. Rev., 111, 517-528, https://doi.org/10.1175/1520-0493(1983)111<0517: TRBEEP $>2.0 . \mathrm{CO} ; 2$.

Rayner, N. A., D. E. Parker, E. B. Horton, C. K. Folland, L. V. Alexander, D. P. Rowell, E. C. Kent, and A. Kaplan, 2003: Global analyses of sea surface temperature, sea ice, and night marine air temperature since the late nineteenth century. J. Geophys. Res., 108, 4407, https://doi.org/10.1029/ 2002JD002670.

Romatschke, U., and R. A. Houze, 2010: Extreme summer convection in South America. J. Climate, 23, 3761-3791, https:// doi.org/10.1175/2010JCLI3465.1.

, and - 2011: Characteristics of precipitating convective systems in the South Asian monsoon. J. Hydrometeor., 12, 3-26, https://doi.org/10.1175/2010JHM1289.1.

_ , S. Medina, and R. A. Houze, 2010: Regional, seasonal, and diurnal variations of extreme convection in the South Asian region. J. Climate, 23, 419-439, https://doi.org/10.1175/ 2009JCLI3140.1.

Ropelewski, C. F., and M. S. Halpert, 1987: Global and regional scale precipitation patterns associated with the El Niño/ Southern Oscillation. Mon. Wea. Rev., 115, 1606-1626, https://doi.org/10.1175/1520-0493(1987)115<1606:GARSPP> 2.0.CO;2.

Seluchi, M. E., A. C. Saulo, M. Nicolini, and P. Satyamurty, 2003: The northwestern Argentinean low: A study of two typical events. Mon. Wea. Rev., 131, 2361-2378, https://doi.org/ 10.1175/1520-0493(2003)131<2361:TNALAS > 2.0.CO;2.

Sen Roy, S., S. B. Saha, S. K. R. Bhowmik, and P. K. Kundu, 2014: Optimization of nowcast software WDSS-II for operational application over the Indian region. Meteor. Atmos. Phys., 124, 143-166, https://doi.org/10.1007/s00703-014-0315-7.

Shimizu, M. H., T. Ambrizzi, and B. Liebmann, 2017: Extreme precipitation events and their relationship with ENSO and MJO phases over northern South America. Int. J. Climatol., 37, 2977-2989, https://doi.org/10.1002/joc.4893.

Souza, E. B. D., and T. Ambrizzi, 2002: ENSO impacts on the South American rainfall during 1980s: Hadley and Walker circulation. Atmósfera, 15, 105-120.

Sulca, J., K. Takahashi, J.-C. Espinoza, M. Vuille, and W. Lavado-Casimiro, 2017: Impacts of different ENSO flavors and tropical Pacific convection variability (ITCZ, SPCZ) on austral summer rainfall in South America, with a focus on Peru. Int. J. Climatol., 38, 420-435, https://doi.org/10.1002/ joc. 5185 .

Tippett, M. K., J. T. Allen, V. A. Gensini, and H. E. Brooks, 2015: Climate and hazardous convective weather. Curr. Climate Change Rep., 1, 60-73, https://doi.org/10.1007/s40641-0150006-6.

Trenberth, K. E., 1997: The definition of El Niño. Bull. Amer. Meteor. Soc., 78, 2771-2778, https://doi.org/10.1175/15200477(1997)078<2771:TDOENO > 2.0.CO;2.

Velasco, I., and J. M. Fritsch, 1987: Mesoscale convective complexes in the Americas. J. Geophys. Res., 92, 9591-9613, https://doi.org/10.1029/JD092iD08p09591.

Wallace, J. M., and D. S. Gutzler, 1981: Teleconnections in the geopotential height field during the Northern Hemisphere winter. Mon. Wea. Rev., 109, 784-812, https://doi.org/10.1175/ 1520-0493(1981)109<0784:TITGHF>2.0.CO;2.

Yoshida, S., T. Morimoto, T. Ushio, and Z. Kawasaki, 2007: ENSO and convective activities in Southeast Asia and 
western Pacific. Geophys. Res. Lett., 34, L21806, https:// doi.org/10.1029/2007GL030758.

Yuter, S. E., and R. A. Houze, 1995: Three-dimensional kinematic and microphysical evolution of Florida cumulonimbus. Part II: Frequency distributions of vertical velocity, reflectivity, and differential reflectivity. Mon. Wea. Rev., 123, 1941-1963, https://doi.org/10.1175/1520-0493(1995)123<1941:TDKAME> 2.0.CO;2.
Zipser, E. J., C. Liu, D. J. Cecil, S. W. Nesbitt, and D. P. Yorty, 2006: Where are the most intense thunderstorms on earth? Bull. Amer. Meteor. Soc., 87, 1057-1071, https://doi.org/ 10.1175/BAMS-87-8-1057.

Zuluaga, M. D., and R. A. Houze, 2015: Extreme convection of the near-equatorial Americas, Africa, and adjoining oceans as seen by TRMM. Mon. Wea. Rev., 143, 298-316, https://doi.org/ 10.1175/MWR-D-14-00109.1. 